Prepared in cooperation with the Navajo Nation's Department of Water Resources, Water Management Branch

Field Manual for the Collection of Navajo Nation Streamilow-Gage Data

Open-File Report $2013=1107$

U.S. Department of the Interior U.S. Geological Survey

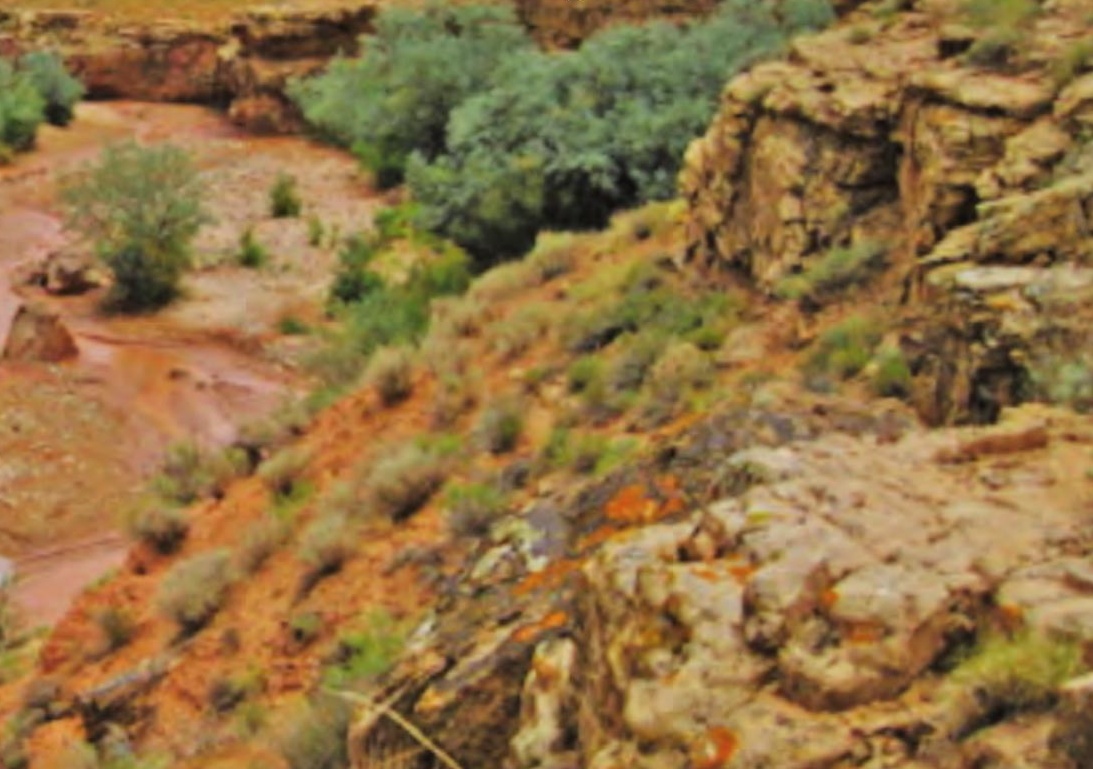


COVER

Lukachukai Creek watershed on the Navajo Nation; photo by Jon Mason (USGS). 


\section{Field Manual for the Collection of Navajo Nation Streamflow-Gage Data}

By Robert J. Hart and Gregory G. Fisk

Prepared in cooperation with the Navajo Nation's Department of Water Resources, Water Management Branch

Open-File Report 2013-1107

U.S. Department of the Interior

U.S. Geological Survey 


\section{U.S. Department of the Interior SALLY JEWELL, Secretary}

\section{U.S. Geological Survey}

\section{Suzette M. Kimball, Acting Director}

\section{U.S. Geological Survey, Reston, Virginia: 2014}

For product and ordering information: World Wide Web: http://www.usgs.gov/pubprod Telephone: 1-888-ASK-USGS

For more information on the USGS - the Federal source for science about the Earth, its natural and living resources, natural hazards, and the environment:

World Wide Web: http://www.usgs.gov Telephone: 1-888-ASK-USGS

Any use of trade, firm, or product names is for descriptive purposes only and does not imply endorsement by the U.S. Government.

Although this report is in the public domain, permission must be secured from the individual copyright owners to reproduce any copyrighted material contained within this report.

\section{Suggested citation:}

Hart, R.J., and Fisk, G.G., 2014, Field manual for the collection of Navajo Nation streamflow-gage data: U.S. Geological Survey Open-File Report 2013-1107, 43 p., http://dx.doi.org/10.3133/ofr20131107. 


\section{Contents}

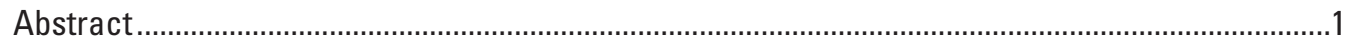

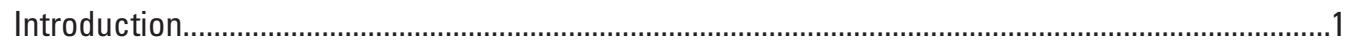

Basics of a Streamflow Gage .......................................................................................................

Determining the Purpose, Need, and Site Suitability of a Streamflow Gage ....................................5

Section I: Steps for Selecting Location of New Streamflow-Gaging Stations ..................................6

Step 1. Determine Channel Characteristics and Requirements .............................................6

Step 2. Establish Measuring Sections and Select Stage Sensors ...........................................8

Step 3. Determine Appropriate Reference Gages..................................................................... 9

Section II: Field Visit Preparation................................................................................................ 11

Previsit Preparation ........................................................................................................... 11

Essential Field Equipment Checklist .....................................................................................13

Flow Meter Care and Maintenance ..............................................................................................13

Section III: Steps for Routine Streamflow-Gage Visits ......................................................................16

Step 1. Make General Observations .........................................................................................16

Step 2. Determine if Instruments are Operating Correctly ......................................................16

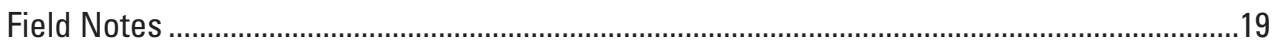

Troubleshooting Instrumentation Problems ...............................................................................20

Section IV: Measurements of Peak-Flow Discharge Using Surveying Methods ..........................21

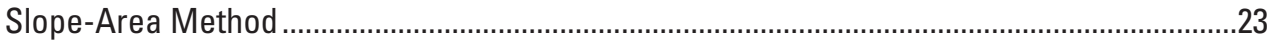


Section V: Safety

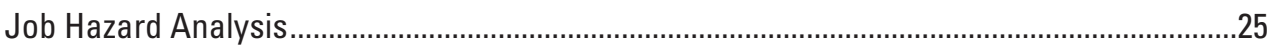

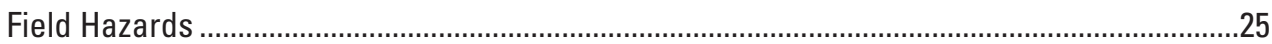

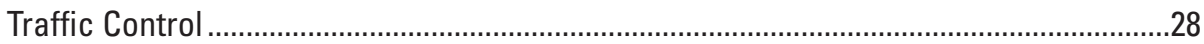

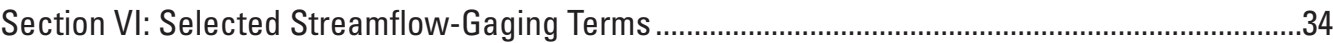

Section VII: Additional Resources by Category..........................................................................

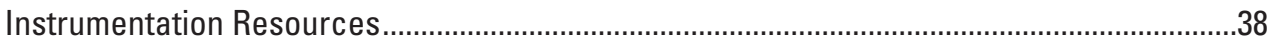

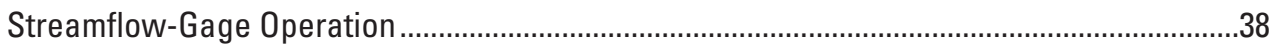

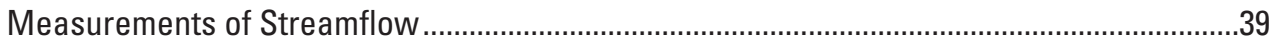

Measurement of Peak Flow Discharge Using Surveying Methods .........................................39

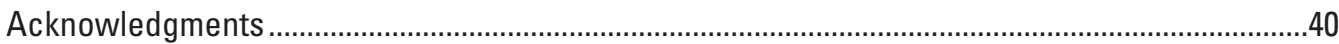

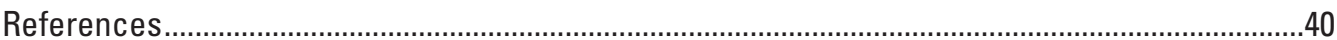

\section{Figures}

1. Map of Navajo Nation showing location of streamflow-gaging stations in Arizona and New Mexico.

2. Diagram of typical stilling well gage and photo of Navajo Department

of Water Resources gage located at Chinle Creek, Navajo Nation 
3. Examples of natural and artificial types of stage control ..........................................................

4. Examples of instruments used to measure stage …………..................................................10

5. Examples of reference gages used to measure stream stage ................................................12

6. Examples of instruments and methods used to measure flow ...........................................15

7. Examples of information needs for indirect measurements of discharge................................22

\section{Tables}

1. Streamflow-gaging equipment and supplies

2. Adjustment factors or component ranges for various channel conditions used to determine Manning's $n$ values

3. Example of a primary job hazard analysis checklist associated with servicing field sites..

4. Example of a primary job hazard analysis checklist associated with environmental hazards

5. Example of a primary job hazard analysis checklist associated with cableway measurement

6. Example of a primary job hazard analysis checklist associated with wading measurements 


\section{Conversion Factors}

\section{Inch/Pound to SI}

\begin{tabular}{|c|c|c|}
\hline Multiply & By & To obtain \\
\hline \multicolumn{3}{|c|}{ Length } \\
\hline inch (in.) & 2.54 & centimeter $(\mathrm{cm})$ \\
\hline inch (in.) & 25.4 & millimeter (mm) \\
\hline foot (ft) & 0.3048 & meter (m) \\
\hline mile (mi) & 1.609 & kilometer (km) \\
\hline \multicolumn{3}{|c|}{ Area } \\
\hline Acre & 0.4047 & square hectometer $\left(\mathrm{hm}^{2}\right)$ \\
\hline Acre & 0.004047 & square kilometer $\left(\mathrm{km}^{2}\right)$ \\
\hline square mile $\left(\mathrm{mi}^{2}\right)$ & 259.0 & hectare (ha) \\
\hline square mile $\left(\mathrm{mi}^{2}\right)$ & 2.590 & square kilometer $\left(\mathrm{km}^{2}\right)$ \\
\hline \multicolumn{3}{|c|}{ Volume } \\
\hline acre-foot (acre-ft) & 1,233 & cubic meter $\left(\mathrm{m}^{3}\right)$ \\
\hline gallon & 3.785 & Liter $(\mathrm{L})$ \\
\hline \multicolumn{3}{|c|}{ Flow rate } \\
\hline foot per second (ft/s) & 0.3048 & meter per second (m/s) \\
\hline cubic foot per second $\left(\mathrm{ft}^{3} / \mathrm{s}, \mathrm{cfs}\right)$ & 0.02832 & cubic meter per second $\left(\mathrm{m}^{3} / \mathrm{s}, \mathrm{cms}\right)$ \\
\hline gallon per minute (gal/min, gpm) & 0.06309 & liter per second (L/s) \\
\hline \multicolumn{3}{|c|}{ Mass } \\
\hline ounce, avoirdupois (oz) & 28.35 & gram (g) \\
\hline pound, avoirdupois (lb) & 0.4536 & kilogram (kg) \\
\hline
\end{tabular}

Temperature in degrees Celsius $\left({ }^{\circ} \mathrm{C}\right)$ may be converted to degrees Fahrenheit $\left({ }^{\circ} \mathrm{F}\right)$ as follows: ${ }^{\circ} \mathrm{F}=\left(1.8 \times{ }^{\circ} \mathrm{C}\right)+32$

Temperature in degrees Fahrenheit $\left({ }^{\circ} \mathrm{F}\right)$ may be converted to degrees Celsius $\left({ }^{\circ} \mathrm{C}\right)$ as follows: ${ }^{\circ} \mathrm{C}=\left({ }^{\circ} \mathrm{F}-32\right) / 1.8$ 


\title{
Field Manual for the Collection of Navajo Nation Streamflow- Gage Data
}

\author{
By Robert J. Hart and Gregory G. Fisk
}

\section{Abstract}

The Field Manual for the Collection of Navajo Nation Streamflow-Gage Data (Navajo Field Manual) is based on established (standard) U.S. Geological Survey streamflowgaging methods and provides guidelines specifically designed for the Navajo Department of Water Resources personnel who establish and maintain streamflow gages. The Navajo Field Manual addresses field visits, including essential field equipment and the selection of and routine visits to streamflowgaging stations, examines surveying methods for determining peak flows (indirect measurements), discusses safety considerations, and defines basic terms.

\section{Introduction}

The Navajo Department of Water Resources' (NDWR) Water Management Branch is responsible for monitoring the streamflow of several Navajo Nation streams and washes. The Navajo Nation covers more than 27,000 square miles $\left(\mathrm{mi}^{2}\right)$ in parts of Arizona, Utah, and New Mexico, and lies within three major river basins: the upper Colorado River Basin, the lower Colorado River Basin, and the Rio Grande Basin. Since the 1980s, the U.S. Geological Survey's (USGS) Arizona Water Science Center (AZWSC) has assisted NDWR hydrographers, including hydrologists and hydrologic technicians, with all aspects of streamflow gaging. Most USGS streamflow-gaging stations measure stage and consist 
of a structure in which instruments used to measure, store, and transmit the stream-stage information are housed. Streamflow information has a wide variety of uses, including flood prediction, water management and allocation, municipal, industrial, and agricultural uses, and recreation. Presently, the Navajo Nation operates and maintains nine streamflow-gaging stations; all are located on the Navajo Reservation in eastern Arizona and western New Mexico (fig. 1). These gages and the primary method for stage monitoring (in parentheses) include:

1. Asaayi creek (pressure-transducer system)

2. Black Creek (float-driven stilling well)

3. Captain Tom Wash (float-driven stilling well)

4. Chinle Creek (float-driven stilling well)

5. Kinlichee Wash (float-driven stilling well)

6. Lukachukai Creek (float-driven stilling well)

7. Tsaile Creek (pressure-transducer system)

8. Wheatfields Creek (float-driven stilling well)

9. Whiskey Creek (float-driven stilling well)
Since the mid-1980s, the USGS AZWSC has been providing technical assistance and training to personnel of the NDWR Water Management Branch for field methods, gage installation and operation, surveying indirect measurements, and surfacewater record computation.

The Field Manual for the Collection of Navajo Nation Streamflow Gage Data (Navajo Field Manual) is based on established (standard) USGS practices and provides guidelines specifically designed for NDWR personnel who establish and maintain streamflow-gaging stations. This step-by-step field manual is designed to assist new and experienced NDWR hydrographers in selecting sites and appropriate instrumentation to be used in streamflow gaging. This manual also includes a checklist of office tasks that are necessary for hydrographers to be efficient in the field. The manual is not intended to be an all-inclusive document on how to streamgage; such information already exists and is available from the USGS (see the Additional Resources section at the end of this guide). The USGS provides formal training to the NDWR concerning streamflow-gaging methods and streamflow-record computation.

This training is part of Federal efforts to help tribal governments to manage their natural resources. 


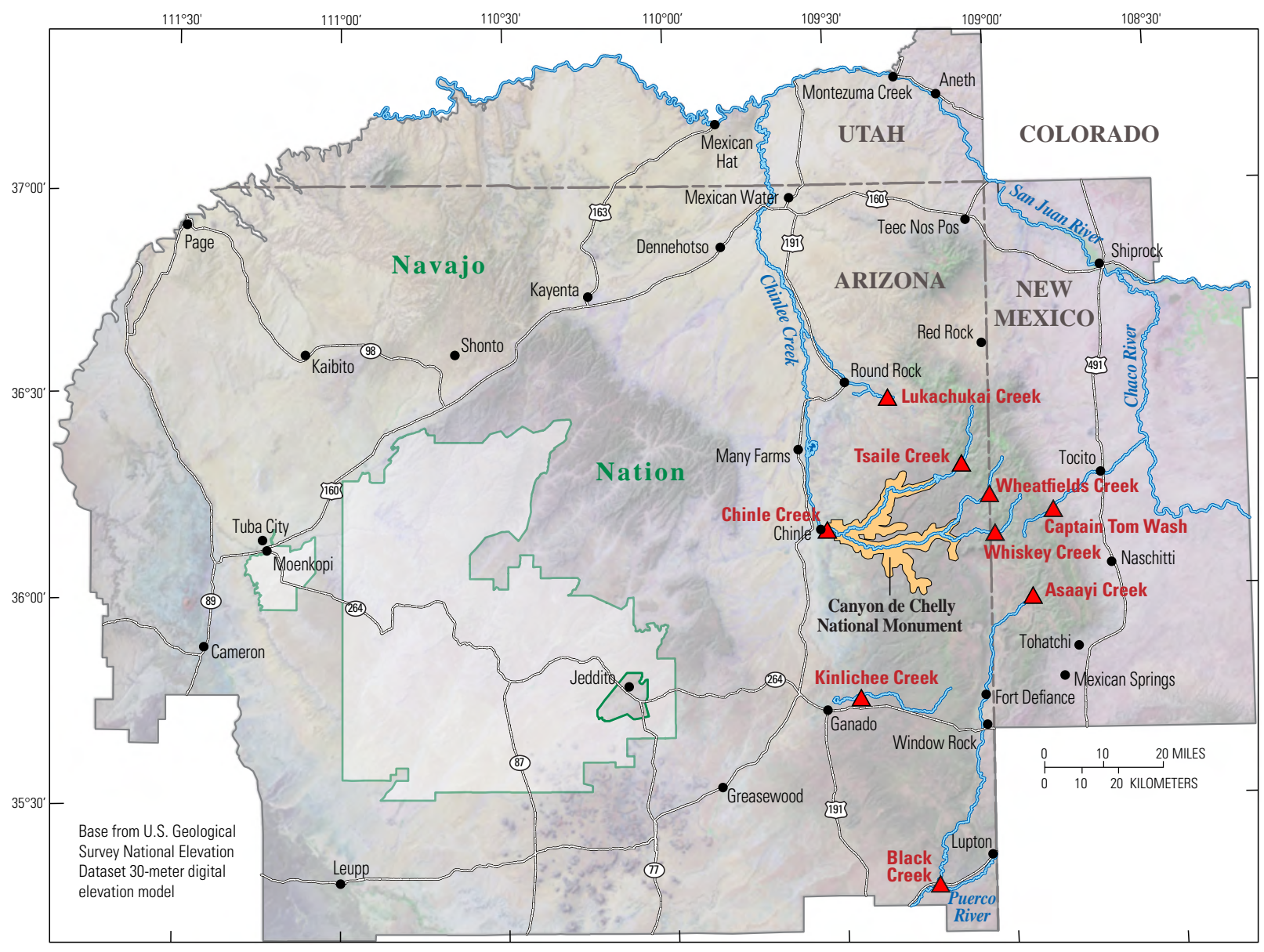

Figure 1. Map of Navajo Nation showing location of area administered by the Navajo Department of Water Resources, Water Management Branch, and streamflow-gaging stations in Arizona and New Mexico.

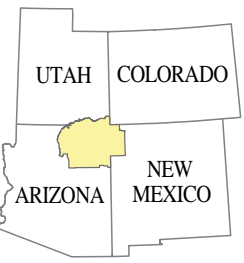

\section{EXPLANATION}

River, stream, creek, or wash

..... Road

Gaging site site name Hopi Reservation boundary

\section{Introduction}




\section{Basics of a Streamflow Gage}

The typical NWDR streamflow-gaging station is a float-driven stilling well (fig. 2). The use of stilling wells is one of the most common methods for measuring stream stage. The stilling well can be installed with intakes from the stream to the well (as shown in fig. 2A) and, therefore, the water level in the well is the same as the stream level. Stilling wells on the Navajo Reservation, however, are installed on the edge of streams and washes and, therefore, do not require the intakes (fig. $2 B$ ). The float is connected to a recorder in the gage shelter and responds to the changing water level in the stream. In the case of NDWR streamgages, the recorder is a strip chart or an electronic recorder. Pressure systems, contact (such as a pressure transducer) and noncontact (such as a WaterLog pressure system with an Accubar transducer), and radar systems provide other methods for sensing stream stage.

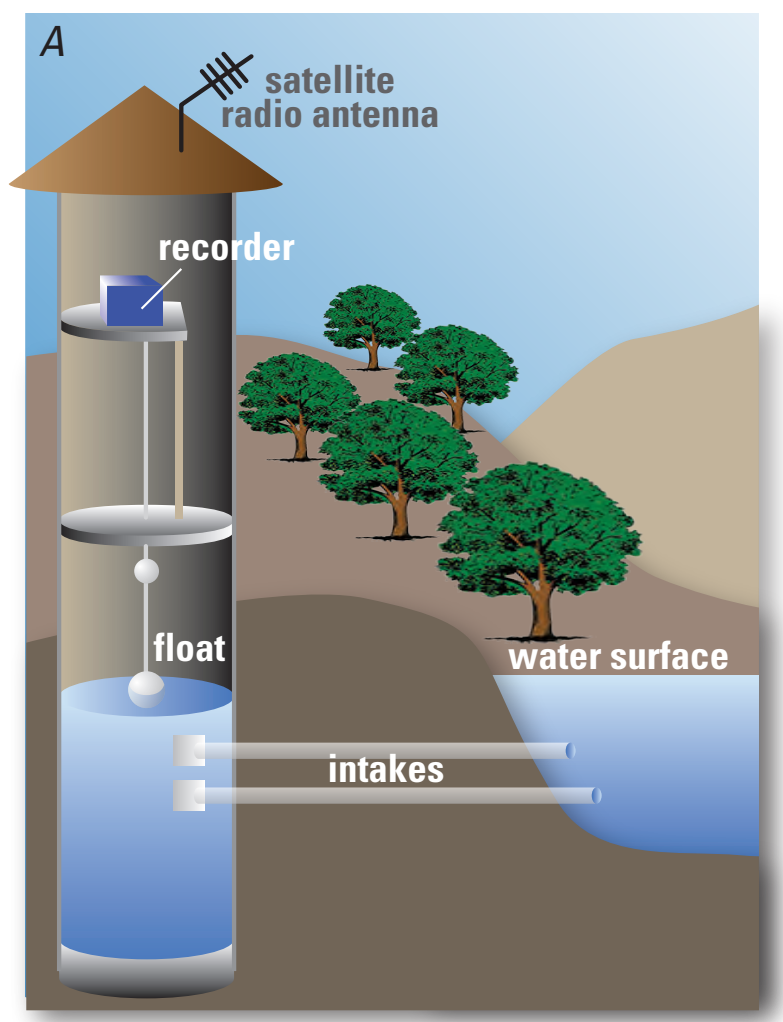

Figure 2. $A$, Diagram of a typical stilling-well gage and $B$, photo of Navajo Department of Water Resources gage located at Chinle Creek, Navajo Nation. 


\section{Determining the Purpose, Need, and Site Suitability of a Streamflow Gage}

Selecting the location of a new streamflow gage (or relocating an old gage) is dependent on the type of data that Navajo Nation managers need to meet their purposes. Streamflow data may be needed for a single purpose - such as early flood warning — or a variety of purposes depending on the general or specific needs for the Navajo Nation. Thus, streamflow gages may be installed to collect data that address the following purposes:

- Measurement of surface-water supply

- Evaluation of surface-water quality for domestic and other uses

- Provision of baseline information to document current conditions

- Protection of water rights

- Provision of early flood warning

In locating a new streamflow gage, hydrographers must be aware of the purpose of the gage and why the streamflow data are needed. For example, if a streamflow gage is used to evaluate the water quality of a spring, the gage must be located close to the source of the spring to minimize the effects of contamination that may be introduced between the spring source and the gage. If the purpose of a streamflow gage is to provide an early flood warning, then the gage should be located far enough upstream from the potentially affected towns or villages to give emergency managers as much time as possible to alert, and possibly evacuate, residents.

Once the purpose of a gage has been determined, the site and channel characteristics will need to be thoroughly reviewed and evaluated for suitability. To evaluate the suitability of potential sites, hydrographers will have to make field visits to gather some critical information that includes:

- Access: Can the site be easily reached by vehicle? How will inclement weather affect access to the site during high-flow events?

- Land ownership or right-of-way: Because there is no private land ownership in most of the Navajo Nation, land ownership is often not a consideration. However, Navajo lands are mingled with private lands and Federal and State lands in the eastern part of the Navajo Nation in New Mexico. Right-of-way access or permissions also may be required by the Navajo Nation.

- Radio transmission (or satellite telemetry): This is important particularly if the streamflow gage is used for flood alert 
or warning. The NDWR typically uses radio communications and, therefore, it is important to locate the gage where the data can be transmitted to a base station.

- Channel and streambed characteristics: Determine if the channel and streambed characteristics are conducive to providing good quality streamflow data. Characteristics to look for include-but are not limited to-the shape, low-flow control, steepness (slope) of the channel, and streambed material (sand, cobbles, boulders, or exposed bedrock).

- Instrumentation: What types of instruments are needed for the site? For example, a stilling well, pressure system, radar, or other.

- Measurement sections: Is a bridge available for high-water measurements, or will some other method for measuring high flows be needed such as a conventional stand-up or sitdown cableway or a cableway that is operated from the bank of the stream? A description of various types of cableways and installations can be found at the USGS Hydrologic Instrumentation Facility Web site at http://wwwrcamnl. wr.usgs.gov/sws/SWTraining/cableways/descr.htm.

\section{Section I: Steps for Selecting Location of New Streamflow-Gaging Stations}

\section{Step 1. Determine Channel Characteristics and Requirements}

1. Determine the type of stage control (natural or artificial) that exists or will need to be installed at the site. See Section VI: Selected Streamflow-Gaging Terms, for a definition of stage controls. Figure 3 shows selected examples of stage controls, which include:

- Bedrock outcrop

- Boulder or gravel bar

- Weirs

- Concrete weir

- V-notch weir

- $\quad$ Broad-crested weir

- Low-water crossing

- Channel control

- Flumes

- $\quad$ Other (describe) 

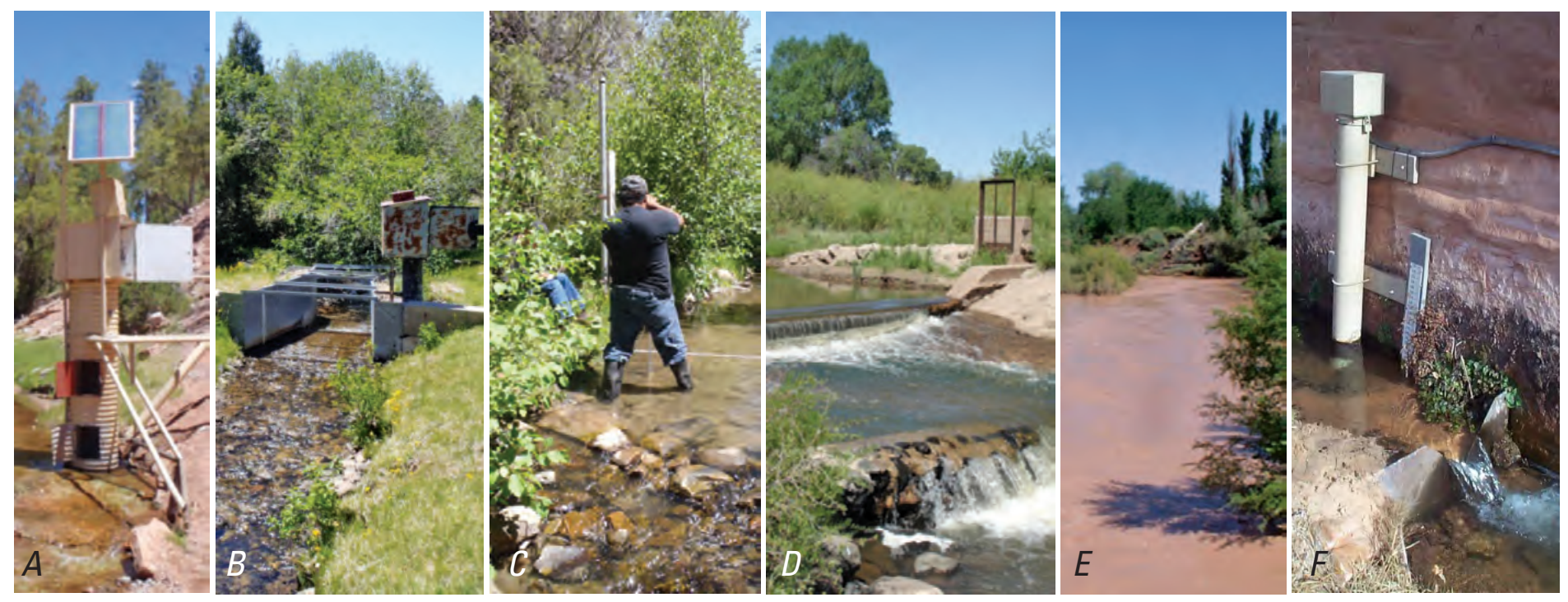

Figure 3. Examples of natural and artificial types of stage control. $A$, Bedrock outcrop, Wheatfields Creek, Navajo Nation; $B$, flume, Whiskey Creek, Navajo Nation; C, boulder and cobble, Asaayi Creek, Navajo Nation; D, Broad-crested weir at the Little Colorado River at Springerville, Arizona; $E$, channel control, downstream of gage at Moenkopi Wash, Arizona; and $F$, v-notch weir, Pasture Canyon Spring near Tuba City, Arizona.

7 Section I: Steps for Selecting Location of New Streamflow-Gaging Stations 
2. Determine streambed and streambank characteristics. A stable streambed will yield a more accurate stage-discharge relation, but it can be challenging to find an ideal streambed in the Navajo Nation. Describe the streambed and streambank characteristics including:

- Bedrock

- Gravel

- $\quad$ Fine-grained sediments such as sand or silt

- Channel shape or the geometry of the channel

- Streambed characteristics (that is, stable or highly erodible)

- Control type (for example, gravel bar, bedrock outcrop, channel, or other control type-note that controls change with the stage and discharge of the stream)

- Slope of the channel (Does the channel reach have a small or large change in elevation?)

- Channel roughness (Does the channel contain large or small rocks, trees or brush? Is the reach straight?)

- Streambed that is subject to scour (for example, finer grained sediments are subject to greater movement than coarser grained sediments such as rock and cobble)

- Streambanks that are subject to sloughing
- Streambanks that have gradual slopes

- Streambanks that have steep slopes

- Streambanks that are heavily vegetated

- Streambanks that are void of vegetation

- Other conditions (describe)

\section{Step 2. Establish Measuring Sections and Select Stage Sensors}

1. Determine measuring sections for low to high flows. When establishing sections, remember measurements should be made in close proximity to the gage and streamflow should be even in the cross section (velocities fairly equal where streamflow is parallel to the banks). For more information on this topic, references are provided in Section VII: Additional Resources by Category. Additionally, hydrographers should select (1) a wading section for low to medium stage and (2) a bridge or cableway measurement location for high flows. If measurements of high flow are not possible, the hydrographer should describe the reach where surveying methods could be used to determine peak flows (this topic is discussed in Section IV: Measuring Peak Flows Using Surveying Methods_-Indirect Method). 
2. Select the appropriate stage sensor and reference gages for reading stage for the site. Stream characteristics and availability of manmade structures such as bridges will govern what type of stage sensor is appropriate. Also, determine if telemetry will be used. Select from the following types of stage sensors (see fig. 4):

- Float drive encoders are suitable for low-sedimentconcentration, nonalluvial and nonmeandering streambeds because they will provide more accurate stage data than streambeds without these characteristics. This type of sensor requires a vertical wall or bridge to attach the stilling well. If the well is subject to freezing, a heat tape or oil tube system may be required. Strip chart recorders or data loggers are used with encoders to read the stage of the stream.

- Submersible pressure transducers are the least expensive of the sensors available, and they are easy to install. Submersible pressure transducers can stand alone or be connected to a data logger. In meandering streams, the sensor can be relocated or multiple sensors can be installed to cover changing stream conditions. This type of sensor is subject to instrument failure from ice and sediment.

- Nonsubmersible pressure transducers require an orifice line. If ice is present or sediment covers the orifice intakes, then this type of sensor is prone to recording erroneous data. Like the submersible pressure transducers, in meandering streams the orifice line can be relocated or multiple orifice lines can be installed to cover changing stream conditions.

- Noncontact radar sensors are suspended over the water, usually from a bridge, and are unaffected by sediment accumulation or transport in alluvial channels. This type of sensor can easily be moved over the channel (if mounted to a bridge crossing) when the stream meanders.

\section{Step 3. Determine Appropriate Reference Gages}

1. Determine the reference gage(s) to be used at the site. Reference gages are used to verify that the data loggers and stage sensors are sensing data correctly. There are various types of reference gages and purposes for using them. In most cases, the USGS uses all three types of reference gages listed below at gage sites. For a complete description of these gages, refer to Section VI: Selected Streamflow-Gaging Terms and Section VII: Additional Resources by Category. Figure 5 shows examples of various types of reference gages. 

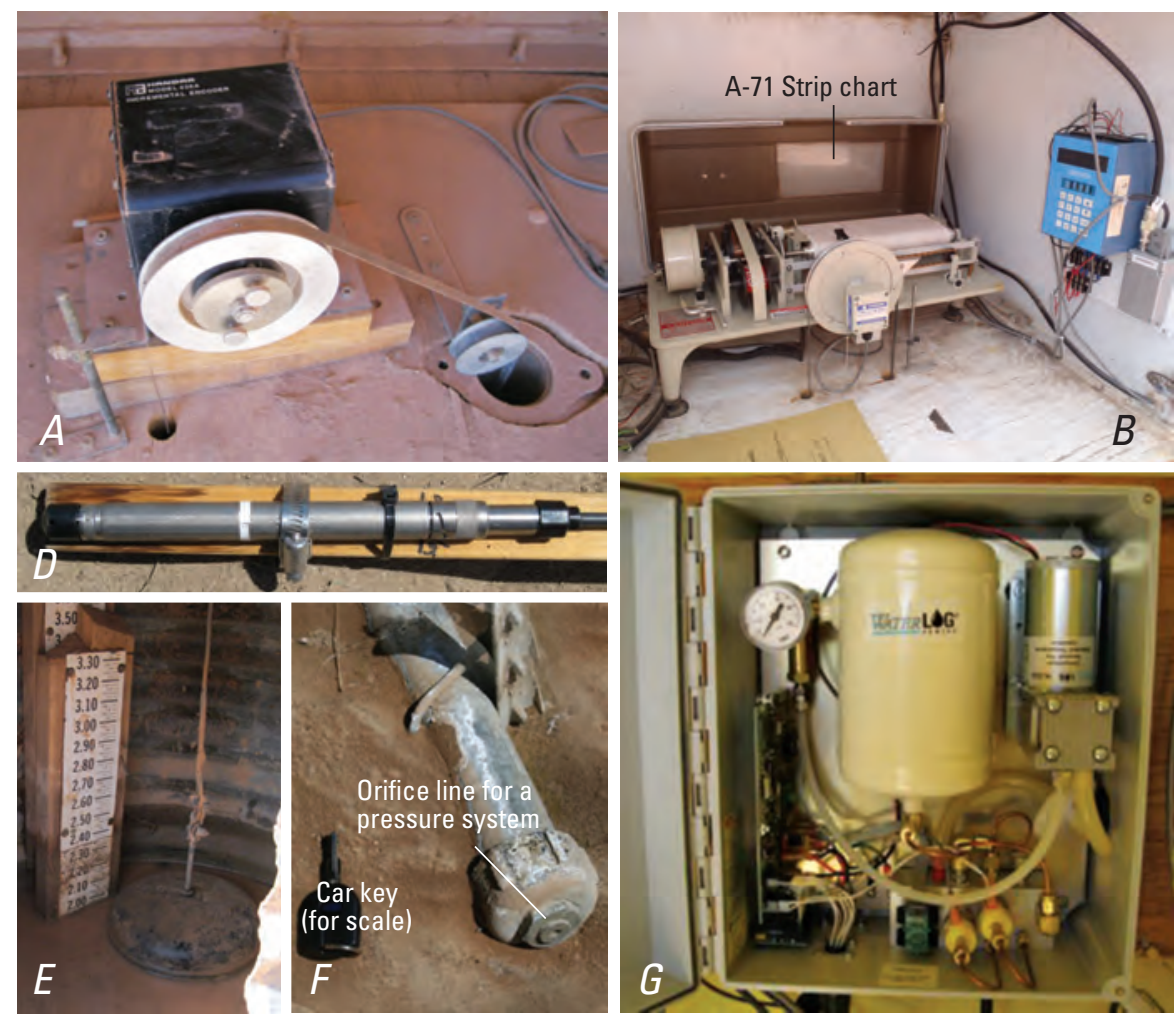

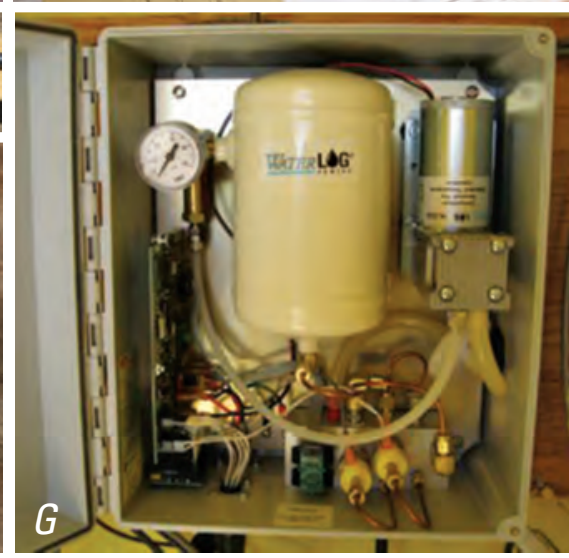

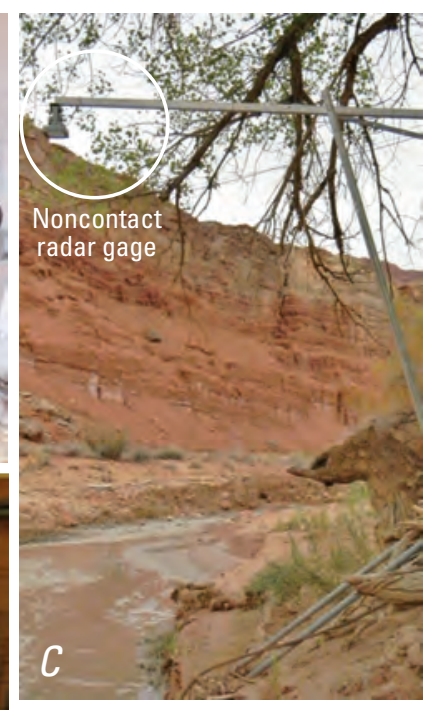

Figure 4.

Examples of

instruments used to measure stage.

$A$, Incremental encoder connected to a float tape that is in contact with the water surface; $B$, shelter at Wheatfields gage with an A-71 strip chart, stage encoder, and a radio data transmitter; $C$, noncontact radar system mounted

to cottonwood tree at Paria River, Lees Ferry, Arizona; $D$, pressure sensor used to measure water pressure (or level); $E$, float system in stilling well and a staff gage, Lukachukai Creek, Navajo Nation; $F$, gas-purge orifice line (exposed in dry wash); and $G$, gas-purge system. 
- $\quad$ Staff gages and reference points (RPs) must be located as close to the stage sensor as possible and in the same gage pool. Staff gages can be read directly to determine the stage of the stream whereas RPs require the hydrographer to tape down to the water surface. The tape-down reading can then be referenced to the predetermined elevation of the RP.

- Crest-stage gages (CSGs) are used to record peak flows for comparison to the primary gage, and they must be in the same gage pool and in an area protected from debris during high flows. The hydrographer should inspect these gages during each routine field trip to assure the CSG is in proper working order.

- Wire-weight gage is a type of reference gage consisting of a wire-wrapped drum and weight; the weight is lowered to the water surface by turning the drum with the attached handle to measure the elevation. That water-surface elevation reading is then compared to the primary gage; elevations from the wire-weight gage and the primary gage should agree within \pm 0.01 feet. These gages require a bridge railing or some other similar type of structure for installation.

\section{Section II: Field Visit Preparation}

\section{Previsit Preparation}

Field visit preparation is critical to ensuring staff safety and making efficient use of time during field visits. A common mistake is putting off field trip preparation until the last minute. Before selecting a streamflow-gage site or making other field trip preparations, the following activities should be completed:

- Understand the purpose for which the data will be collected.

- Review the work plan and know the types of measurements and samples needed.

- Make a field reconnaissance trip before selecting streamflowgaging locations, noting conditions that could affect streamflow gaging activities.

- Review site files and field folders, noting location, description, access, and previously collected data for each site to be visited.

- Obtain and keep current with the training requirements associated with the hydrographer's data-collection activities (adapted from Wilde and others, 1998). 


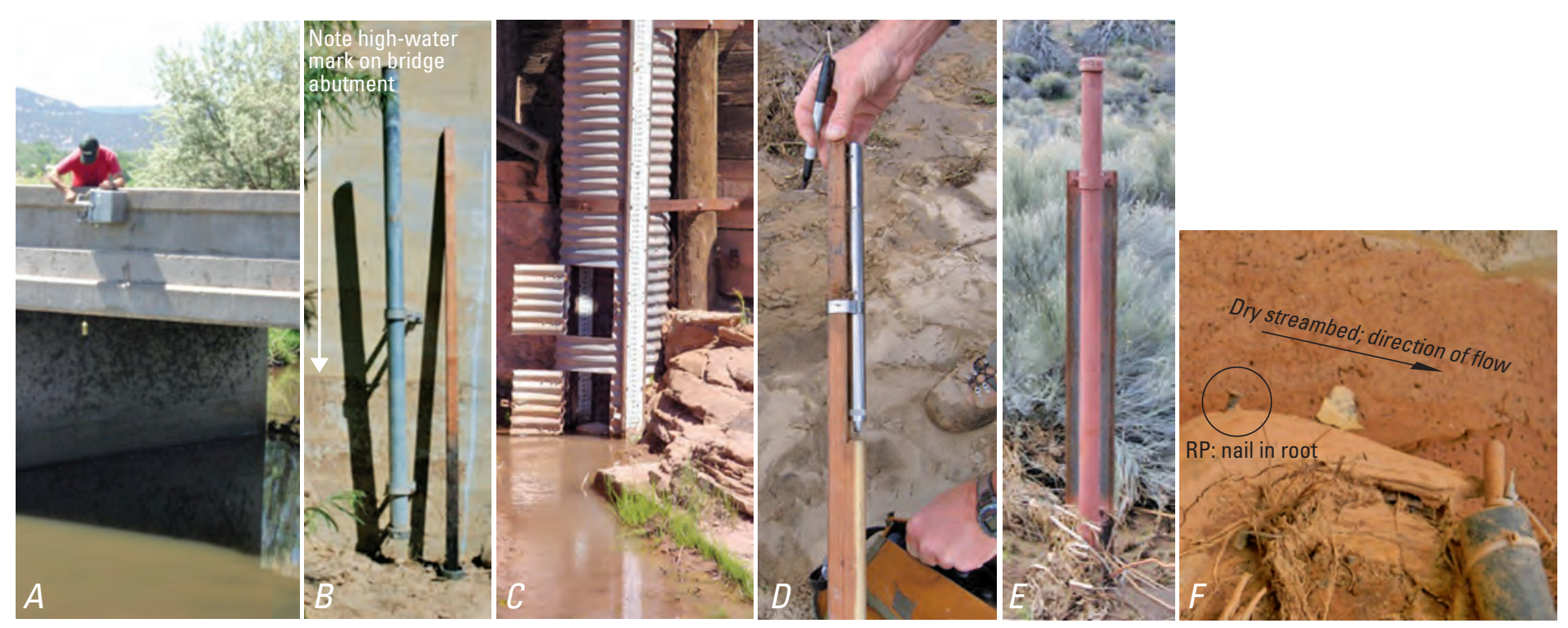

Figure 5. Examples of reference gages used to measure stream stage. $A$, Wire-weight gage mounted to the bridge at Springerville, Arizona; $B$, crest-stage gage with measuring stick removed (arrow points to high-water mark on the concrete abutment); $C$, inside and outside staff plates, Kinlichee Creek, Navajo Nation; $D$, pressure sensor of a continuous-slope area gage, Williamson Valley, Arizona; $E$, continuous slope-area gage-pressure sensor (shown in fig. $5 D$ ) is housed in steel pipe-Williamson Valley, Arizona; and $F$, reference point (RP; nail in root) used to tape down to the water surface. 


\section{Essential Field Equipment Checklist}

This section of the Navajo Field Manual provides a checklist of essential field equipment. A more comprehensive list is provided in table 1. Field vehicles should be equipped for routine and emergency gage-repair trips and ready to depart on flood trips in an efficient manner. The hydrographer is responsible for ensuring that proper field equipment is available and in good working order. Because most streamflow-gaging stations are located in remote areas, it is advisable to pack food, water, and extra clothing.

\section{Flow Meter Care and Maintenance}

The care and calibration of flow meters, or current-velocity meters, is the most critical element of previsit preparation. Flow meters that will function accurately in the flow conditions of the stream (for example Price Pygmy or AA meters) should be taken on each site visit; it also is recommended that hydrographers take a spare flow meter with them into the field in the event of equipment failure. Although requirements differ for mechanical and acoustic flow meters, the following general care and maintenance activities are recommended:
- Maintain meter-calibration log books to track the performance of meters; logs can help detect decreased efficiency resulting from poor (damaged) meter pivots or low batteries.

- Replace batteries for acoustic meters and the AquaCalc on a routine basis.

- Confirm electrical continuity for mechanical flow meters (Price AA and Price Pygmy current meters) before each field trip.

- Perform spin tests before and after each field trip and after meter repairs. Also, if streams are laden with sediment or debris, it is suggested to perform a spin test before and after the discharge measurement is made. This should be done in a controlled environment such as the cab of a vehicle to eliminate any effects from wind. The minimum spin time is 2 minutes for a Price AA meter and 45 seconds for a Price Pygmy meter. Results of the spin test should be noted on the front sheet of the field notes as "ok" or "free" to indicate a visual check was acceptable (Turnipseed and Sauer, 2010).

- Check and test suspension reels (Type A or B-56 sounding reels) twice a year to ensure electrical connections are good between the reel and the meter. Examples of instruments used to measure flow are shown in figure 6 . 
Table 1. Streamflow-gaging equipment and supplies.

[Note: the hydrographers will include other types of equipment or supplies that they feel are necessary and preferential that may not be listed here]

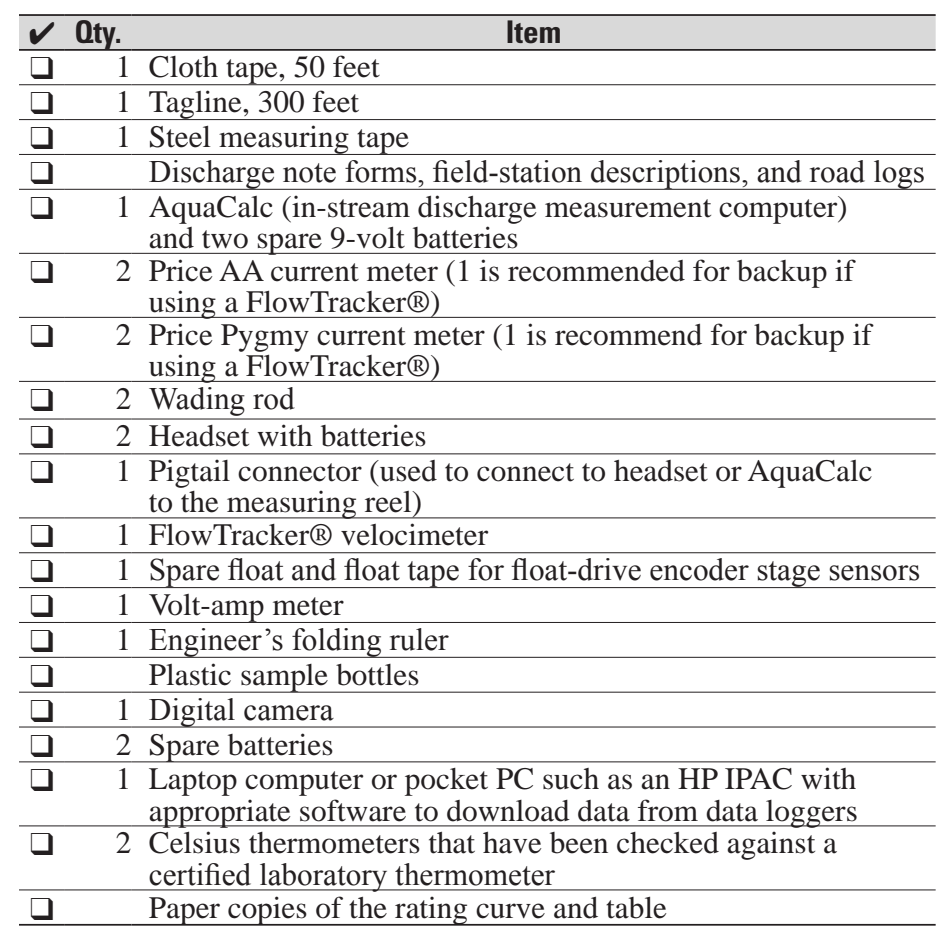

\begin{tabular}{|c|c|}
\hline$\checkmark$ & Item \\
\hline$\square$ & $\begin{array}{l}\text { Navajo Department of Water Resources Flood Plan, if } \\
\text { available }\end{array}$ \\
\hline ב & 1 pr Chest waders \\
\hline$\square$ & 1 pr Hip boots \\
\hline$\square$ & 1 Rain gear \\
\hline 口 & 2 Personal floatation device \\
\hline 口 & 1 Skin protection such as sunscreen \\
\hline & Special equipment for high-flow or flood measurements \\
\hline$\square$ & Bridge and cable measuring equipment \\
\hline D & 1 Bridge board and 4-wheel base bridge boom \\
\hline ב & 4 Counter weights for the 4 -wheel base crane, 50 pounds \\
\hline$\square$ & $\begin{array}{c}1 \text { ea } 30-, 50-, 75-, 100 \text {-pound sounding weights (150-pound } \\
\text { sounding weight, if available); for use with the Price AA } \\
\text { current meter during high flows from bridges or cableways. }\end{array}$ \\
\hline 口 & 2 Sounding-weight pins and hanger rods \\
\hline$\square$ & 1 B-56 sounding reel with quick-release mechanism \\
\hline ב & 1 Type A sounding reel \\
\hline ב & 1 Hand level \\
\hline ב & 1 Roll of flagging tape for marking HWMs \\
\hline ב & 1 Cable car puller \\
\hline & Miscellaneous equipment and supplies \\
\hline D & Tool kit \\
\hline D & Flashlight with extra batteries \\
\hline D & Cellular or satellite phone \\
\hline ב & First aid kit \\
\hline
\end{tabular}




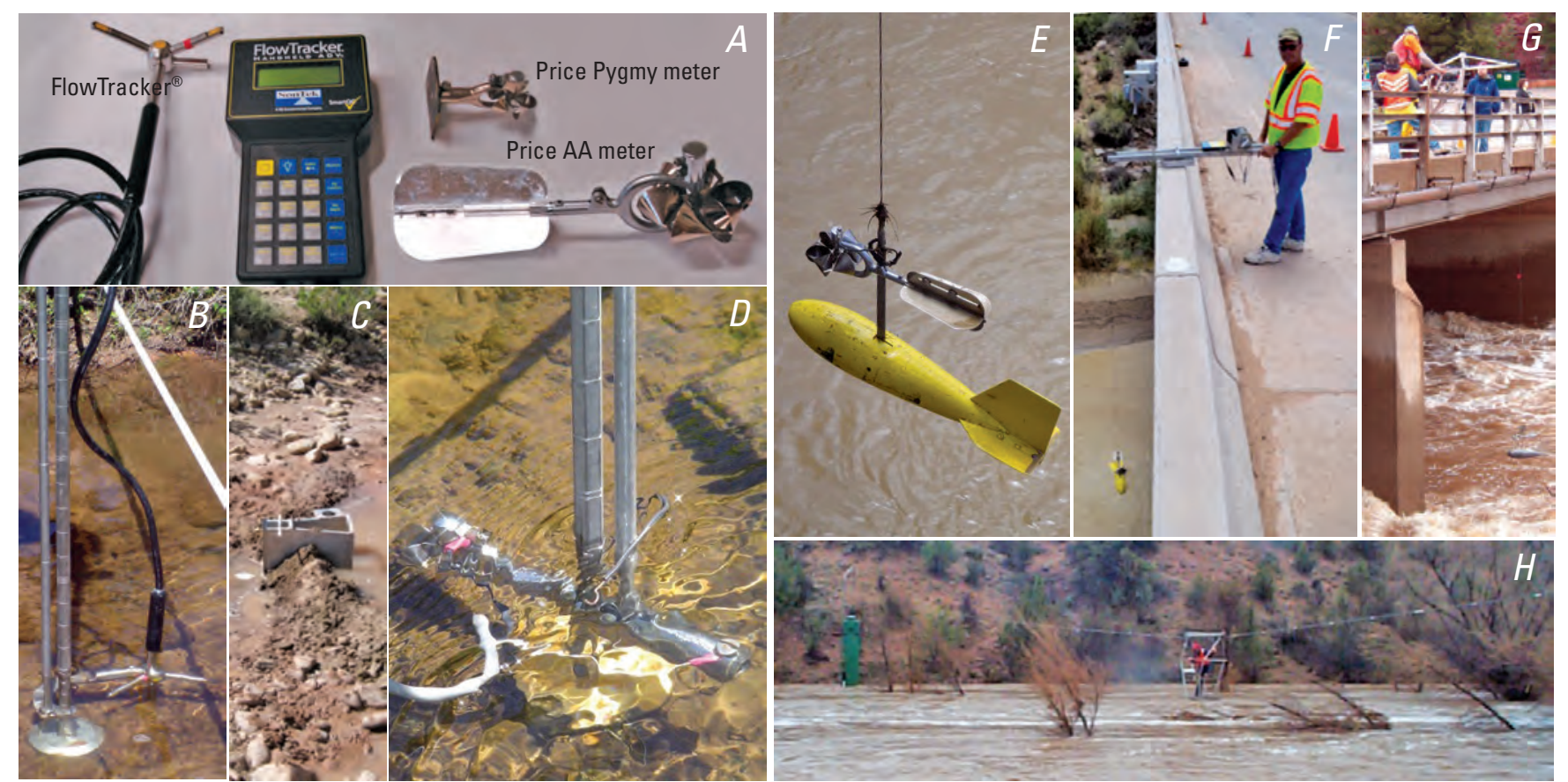

Figure 6. Examples of instruments and methods used to measure flow. $A$, Three types of flow meters (FlowTracker ${ }^{\circledR}$, Price Pygmy, and Price AA); $B$, FlowTracker ${ }^{\circledR}$ in use at Kinlichee Wash, Navajo Nation; $C$, Parshall flume, Captain Tom Wash, Navajo Nation; $D$, Pygmy meter in use at Kinlichee Wash, Navajo Nation; $E$, Price AA meter attached to 30-pound sounding weight, Moenkopi Wash, Arizona; $F$, measuring high flow using a bridge board at Moenkopi Wash, Arizona; $G$, measuring high flow using a bridge boom at Oak Creek, Sedona, Arizona; and $H$, measuring high flow from a cableway at Verde River, Paulden, Arizona. 


\section{Section III: Steps for Routine Streamflow Gage Visits}

If streamflow gages are equipped with telemetry or radio communications, data can be scanned remotely from the office, field, or home (if Internet service is available) to identify possible instrument problems and to determine current conditions of streamflow.

\section{Step 1. Make General Observations}

1. Upon arrival, set out safety equipment. Prepare and assemble necessary equipment. Park vehicle in a location and direction so as not to block the roadway.

2. In the field notes (see below), record the current stage of the stream from the following gages:

- Reference gages (reference points, staff plates, or wireweight gage)

- Data logger

- Float-drive encoder
3. Make general observations of the site in the field notes.

4. Take photos of the stage control and the gage reach. Document any changes you report in the field notes, and be sure to record the photo number along with a description.

5. Inspect the gaging station, the shelter, and the instruments. Write appropriate observations in the field notes.

6. Inspect the crest-stage gage (CSG) and peak-stage indicator (PSI) for high-water marks (HWMs). The PSI is a simple clip that attaches to the steel tape and marks the highest stage on the tape. Inspect other sources where HWMs may be documented, including in stilling wells or along the streambanks. If HWMs are found along the streambanks, use flagging and large nails to mark the HWM line upstream and downstream of the gage or, if already selected, in the slope-area reach of the gage.

\section{Step 2. Determine if Instruments are Operating Correctly}

1. Determine if the stage sensor (the primary gage) is operating correctly. Good notes are required regarding the condition and the results of testing the sensors for proper operation. 
Any changes in stage that result from testing the sensors need to be documented in the field notes. If errors are found after the tests are completed, reset the data logger to reflect the corrected stage. Use the following methods for verifying the operation of each specific sensor:

- Check float-driven encoders by rotating the steel tape wheel and observe if the stage changes on the encoder (fig. 4A).

- Purge nonsubmersible transducers by increasing the gas pressure in the orifice line for about 1 minute. Ream the orifice line where it is exposed to the stream to ensure that it is not plugged with debris. Following the purge, test the transducer's operation by temporarily plugging the orifice line where it is exposed at the stream. A change in stage (an increase) should be observed with the data logger and, after the plug is removed, the stage should return to the previous reading.

- While observing changes on the data logger, raise and lower submersible transducers in the stream to ensure they are operational.

2. Check noncontact sensors such as radar sensing equipment on all gage inspections. If there is not a significant change in stage during inspections, test the sensor manually by holding a piece of poster board under the sensor while it is scanning data and verify that the stage is changing.

3. Check the battery voltage and record results in the field notes. If the voltage is less than 12 volts, replace the battery. Also, if available, check the amperage with an amp meter. The amp meter will measure the strength of an electric current and, therefore, provide the hydrographer with information about the strength of the battery.

4. Determine what the stage control is at the current stage and where the control is in relation to the gage. Document in the field notes and take photographs of the condition of the control. For example, note whether or not there is debris on the control, if aquatic growth in the channel is present, or if scour in the streambed has occurred since the last visit. [Note: All these factors affect the control reach by raising or lowering the stage of the control reach-which in turn affects the stage-discharge rating for the site. Rating shifts are often applied to discharge measurements when these conditions occur to account for more or less water at the site.]

5. During several visits to the site, determine the point of zero flow (PZF) by measuring the low point of the stage control. The PZF is the lowest point of the control where flow ceases. 
This information is particularly important for streams that go dry periodically.

6. Make the discharge measurement in the vicinity of the gage at the best possible cross section for a given stage. Check the flow meter for performance by conducting a spin test (as discussed earlier in the "Flow Meter Care and Maintenance" section of this guide) before and after each field trip (Turnipseed and Sauer, 2010). Discharge measurement notes, a preprinted type of field notes (USGS form 9-275-F), provide a place for documenting the spin test.

7. Estimate the discharge if a rating curve and table are not yet developed for the site in order to determine what method and flow meter to use. The discharge can be estimated by determining the width (in feet) of the measuring section and estimating an average depth (in feet) and velocity (in feet per second); width $\mathrm{x}$ depth $\mathrm{x}$ velocity=discharge in cubic feet per second $\left(\mathrm{ft}^{3} / \mathrm{s}\right)$. An average velocity can be estimated by floating a stick or other buoyant item between a measured distance, noting the travel time, and multiplying that time by distance and by 0.8 .
8. Determine the discharge from the rating table if the site has a developed rating curve (this should be available in the hydrographer's field folder) using the existing stage reading. The discharge from the rating will help the hydrographer determine what method and flow meter to use for measuring the flow. If the flow is extremely low, a volumetric method may be the only choice. For discharge values between 0.1 and $0.4 \mathrm{ft}^{3} / \mathrm{s}$, use a Parshall flume (see "Section VII: Selected Streamflow-Gaging Terms"). For discharge greater than $0.4 \mathrm{ft}^{3} / \mathrm{s}$, use a Price AA or Price Pygmy current meter or a SonTek FlowTracker ${ }^{\circledR}$.

9. Ensure that the measurement documents all discharge that passes the gage; there should be no secondary streamflow that is not accounted for by the gage. An example of secondary flow would be a secondary stream channel that may divert flow around the gage (upstream of the gage) and therefore not be accounted for.

10. The ideal channel cross section for a measurement would be a firm sand-gravel or bedrock bottom with even (equal) depths and velocity. This condition is rare in many Navajo Nation streams and washes. 
11. Use 25 to 30 vertical subsections within the measuring section (with a goal of no more than 5 percent of the flow in any section) in a typical measurement cross section.

12. Compute the discharge after completing the measurement on site (see "Section VII: Additional Resources by Category-Measurements of Streamflow;" Rantz, S.E., and others, 1982). Plot the discharge on the rating curve (a rating curve and table for the gage should be kept on site in the gage house as well as in your field folder). If the measurement plots more than 5 percent away from the rating curve, and there has not been a significant change to the control, a check measurement is required. The check measurement is made with a different meter and in a different cross section of the reach.

13. After the discharge measurement has been completed, read all gages (primary and reference gages) again, determine an average gage height for the measurement, and record in the field notes.

14. Check the data logger and transmitter for proper operation before leaving the gage site. Be sure the shelter is locked and secured.

\section{Field Notes}

Good field notes provide the basis for producing quality streamflow records and correctly analyzing the data. For these reasons, a protocol should be established for data-collection activities; measurement and inspection notes should be complete and made at the gage site. One way to capture all relevant information is to use USGS Discharge Measurement Notes, which are printed on waterproof paper and can be ordered online at http://www.rickly.com/sga/usgsforms.htm. These preprinted forms are formatted to USGS requirements (Form 9-275-F), and the front cover includes specific fields for recording the following information:

1. Condition of the site: indicate if the site has been vandalized or damaged by high water.

2. Condition of instrumentation: indicate if the instruments have been damaged or vandalized or are not working for other reasons.

3. Changes in the gage reach: indicate if changes have occurred because of high water or streambank eroding or calving.

4. Condition of the stage control: indicate whether the stage control has been modified or damaged in any way. For example, has the natural stage control been scoured by high flows? Has the artificial control, such as a V-notch weir, been damaged or clogged with debris? 
The front cover of the field notes also provides space to record detailed information related to the discharge measurement and stage of the stream. The rest of the form is used for noting measurement information for each subsection measurement in the cross section.

\section{Troubleshooting Instrumentation Problems}

Troubleshooting data loggers and stage sensors can be difficult because of the complexity of their electronics. In many cases, instrument components can be replaced, which will often solve the problem. However, the most common cause of instrument failure is loss of power to the instrument. This type of problem is easy to diagnose and repair by (1) checking all electrical connections to be sure they are secure and (2) using a voltmeter to check the voltage of the instruments to be sure the power available is adequate. If the voltage is low, it can be due to excess power consumption in the instrument; the instrument should be repaired or replaced, if this is the case. If the gagehouse equipment is powered through a solar panel, that may be the source of the problem-solar panels eventually wear out and need to be replaced. Another common cause for electrical problems or failure is the regulator-if it fails, the battery will not be charged. The following is a list of common problems related to specific instruments:

- Float-driven encoder systems seldom fail, but when they do fail, the most probable cause is related to loss of power to the encoder, damage to a sinking float, or the steel tape disengaging from the float-wheel spline during high-flow events.

- Nonsubmersible transducer systems are subject to pressure leaks in the orifice line and ice or debris buildup over the orifice intake. These problems can be diagnosed by simply observing the stage record, which will reflect erroneous stage data. If a pressure leak is occurring, the stage record will reflect a lower-than-normal stage because of the loss of pressure. If ice or debris has accumulated on the orifice line, the stage will reflect a higher-than-normal stage because of the increase in pressure. Pressure leaks are difficult to locate, but in many cases, leaks can be detected by applying soapy water around connections or suspected areas of damage to the orifice line. The leaking gas will create bubbles in the soapy water.

- Submersible transducer systems simply fail over time and cannot be repaired, so replacement of the transducers is the only option. 
- Noncontact sensors such as radar units can only be checked when there is water in the gage pool or by reflecting the radar wave off a piece of poster board. If the sensor does not agree with the reference gage, this lack of agreement may be a sign that the sensor is failing. The sensor should be checked, verified, and if necessary, replaced.

\section{Section IV: Measurements of Peak-Flow Discharge Using Surveying Methods}

The measurement of peak-flow discharge is an important element in collecting a good hydrologic record of streamflow. Because of the flashy nature of high flows on Navajo Nation streams and washes, and also the inability to access a gage in a timely manner, it is difficult to obtain a measurement of peak flows using standard measurement methods. When the hydrographer cannot make a measurement, surveying methods can be used to determine the discharge following the high-flow event. These methods are referred to as "indirect methods" of determining peak-flow discharge. Indirect measurement methods require a team of hydrographers to survey cross sections of the channel in the vicinity of the gaging station and determine channel geometry and slope from a series of high-water marks. The surveyed cross section provides information about the depth of the channel and the geometry of the stream. Using a series of at least three cross sections, the slope of the surveyed reach can be calculated. The geometry of the reach and the slope can then be used to compute the discharge. Examples of information needs for making indirect measurements of discharge are shown in figure 7.

There are several methods of making indirect measurements, including the following:

- Contracted bridge openings

- Flow-through culverts

- Slope-area computation

- Flow-over weirs

- Step-backwater model analysis

Step-backwater models, such as HEC-RAS (a U.S. Army Corps of Engineers model, available at http://www.hec.usace. army.mil/software/hec-ras/hec-georas downloads.html), are normally used for initial rating-curve development but can also be used to determine peak flows. However, they require more crosssection surveys. Because most of the Navajo Nation's streams and washes are natural, open channels, the slope-area method will be used in most cases. The following section describes the steps and data needed for the slope-area method of computing discharge. 


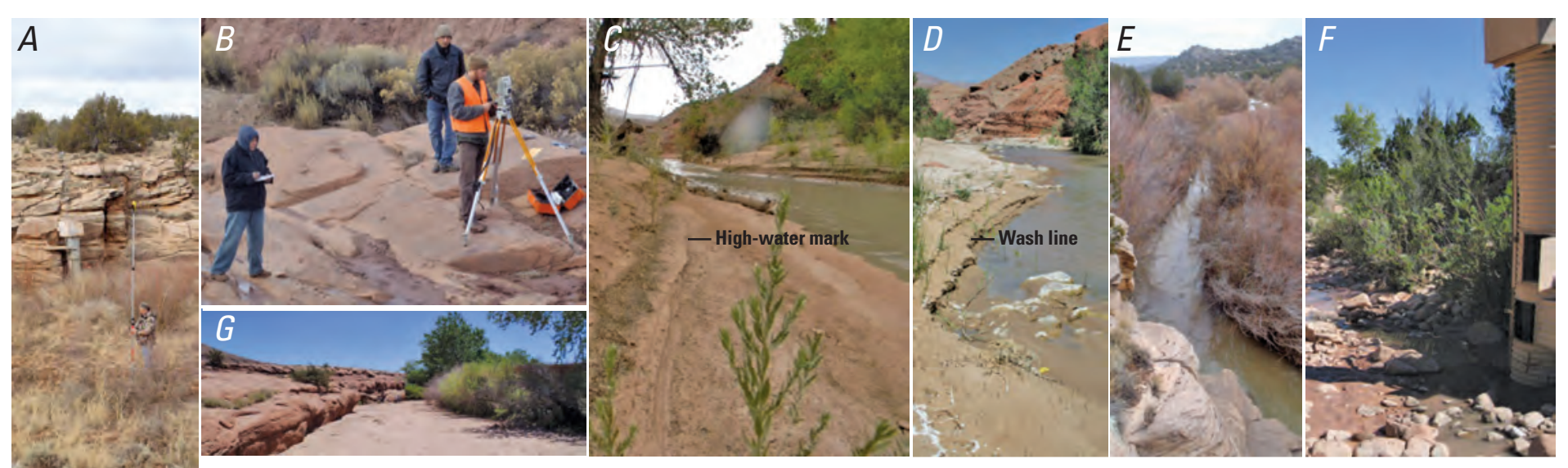

Figure 7. Examples of information needs for indirect measurements of discharge. A, Cross section at Black Creek, Navajo Nation; $B$, surveying crew (Joel Unema, U.S. Geological Survey, Bel B. Pachai and Linda Lee, Navajo Department of Water Resources) at Kinlichee Creek, Navajo Nation; $C$, high-water mark along Paria River, Lees Ferry, Arizona; $D$, wash line along Paria River, Lees Ferry, Arizona; $E$, example of channel roughness with sand channel and vegetation along active channel, Black Creek, Navajo Nation; $F$, example of channel roughness with vegetation and large cobbles along the active channel, Captain Tom Wash, Navajo Nation; and G, example of channel roughness with vegetation along active channel, Chinle Wash, Navajo Nation. 


\section{Slope-Area Method}

The slope-area method of determining discharge is based on surveying cross sections (typically three), calculating the watersurface slope from cross-section geometry, and assigning roughness values (see discussion below, in the section called "Channel Roughness") that describe the channel-reach geometry and highwater marks (HWMs) on both sides of the banks. Data collected from the survey are entered into a USGS slope-area computer program (SAC; see "Section VIII: Additional Resources by Category," Fulford, 1994). The SAC follows USGS standardized procedures for computing discharge by the slope-area method. The program solves the 1-D steady-state energy and continuity equations for discharge given upstream and downstream watersurface elevations. As with computing discharge directly with current-velocity meters, the collection of accurate field data is critical. A level, or total station transit, is needed for surveying the channel reach and collecting other elevation data that are required. The following is a list of important tasks and observations that need to be made to employ the slope-area method:

- High-water marks (HWMs) are an important piece of information needed for the slope-area method; they are used to define the depth and slope of the water surface between the cross sections for a particular flow event. HWMs are the accumulation of debris - seeds, grass, small limbs or twigs, or wash lines-along the streambanks and indicate the highest stage (elevation) of the high-water event. These marks can also be found along canyon walls and around tree trunks. Be aware that some HWMs may provide an erroneous reading; typically these types of HWMs can be found in tree limbs or other vegetation that is not rigid enough to withstand the high velocities that can occur during high flows. HWMs will quickly degrade or erode as time passes, so it is extremely important to visit the site as soon as possible following a flood or high-flow event. Tying flagging to long nails provides an easy method for marking HWMs. Both banks are flagged with 15 to 20 marks, depending on the length of the reach, and these HWMs are surveyed along both banks in the entire reach if possible.

- Channel-reach geometry should be relatively straight and of equal width or slightly contracting as it goes downstream. Ideally the channel reach should be in the vicinity of the gage. The discharge calculation will be more accurate if the banks and channel are stable and free of brush and debris. The discharge estimate is also more accurate if the flow is confined to one channel with no overbank flow. In most cases, alluvial sand channels are poor indirect channel reaches because the

\section{Section IV: Measurements of Peak-Flow Discharge Using Surveying Methods}


stream bed is unstable and the channel geometry during the peak flow may be significantly different than indicated from the postflow cross section surveys. In general, the length of the reach should be equal to or greater than 75 times the mean depth in the channel (Dalrymple and Benson, 1984).

- Channel cross sections are selected based on the channel geometry and a minimum of 3 are recommended for slope-area calculations. Criteria for selecting cross sections are described by Benson and Dalrymple (1967).

- Surveying the HWMs and cross sections requires the use of a level or a total station transit. The survey levels are first run to the HWMs on both banks. Streamwise distance (x coordinate), cross-stream distance (y coordinate), and elevation (z coordinate) are measured at all the HWMs. A highwater surface profile is then drawn using a computer program (see "Section VII: Additional Resources by Category;" Fulford, 1994) or can be hand-drawn using the surveyed data and used to determine the location of the channel cross sections. Crosssections typically have 15-20 points that define the breaks in slope and the general geometry of the cross sections.

- Channel roughness is an estimate that needs to be made while in the field. Roughness parameters (Manning's $n$ ) are coefficients that have been developed for various channel conditions that affect the depth and velocity of flow. Channel conditions including irregularity of the channel, cross section variation, channel obstructions or material, vegetative growth on the channel banks and in the channel, and the meanders of the stream affect the flow (velocity and volume) of water during a flow event. These channel conditions are used to adjust the roughness coefficient (Manning's $n$ ) and can range from 0.030 for sand channels clear of vegetation to greater than 0.065 for heavily vegetated channels with boulder streambeds. Streams with higher roughness coefficients will convey less water. Table 2 can be used to determine the roughness coefficient for indirect measurement of peak flow discharge by summing the Manning's $n$ adjustment for each channel condition. For more in-depth information on this topic, see Section VII: Additional Resources by Category; Aldridge and Garrett (1973); and Phillips and Tadayon (2006).

- $\quad$ Notes and photographs should be taken using transit-level field notes that are available commercially or through the USGS. As with a site visit to a gage, accurate level notes are necessary to compute discharge from indirect methods. Photographs should be taken to document HWMs, cross section reaches, and roughness characteristics. 
- Final computation of discharge using the data collected for the slope-area method can be done by hand or with the USGS slope-area computer program (Fulford, 1994). Using either method, Microsoft Office Excel spreadsheet works extremely well for transposing field notes of cross-section data; the data can be worked by hand or easily imported into the USGS SAC program to produce discharge and other pertinent information.

\section{Section V: Safety}

\section{Job Hazard Analysis}

Safety is the number one priority for all hydrographers in the field, especially in remote areas. A Job Hazard Analysis (JHA) includes a list of hazards associated with each gage site and should be written for every site. JHAs should include environmental hazards as well as work-related hazards. Examples of hazards to be included in JHAs are as follows and are shown in tables 3-6:

- Fast and deep water

- Temperature-heat and cold

- Poisonous snakes and insects
- Rough terrain

- Quicksand-this is a real and dangerous hazard in sand-bedded streams

- Other environmental hazards

- Inadequate swimming ability of the hydrographer

The USGS provides detailed instruction as to what is required in a JHA (available online at http://www.usgs.gov/usgs-manual/ handbook/hb/445-2-h/ch15.html) and OSHA (Occupational Safety and Heath Administration) provides an online booklet at http:// www.osha.gov/Publications/osha3071.pdf.

\section{Field Hazards}

Perhaps the most important precautionary practice the hydrographer can do to avoid field hazards is to prepare a trip itinerary and leave a copy with the supervisor or other designated persons. The itinerary should include phone numbers where the hydrographer can be reached, trip route, and lodging or camping information. In most cases, cell phone coverage is available on the Navajo Nation and, therefore, a cell phone should be carried at all times. Enter the telephone numbers of nearby hospitals and other emergency facilities in your cell phone, and have a written list in your vehicle and/or on your person that includes their location.

25 Section V: Safety 
Table 2. Adjustment factors or component ranges for various channel conditions used to determine Manning's $n$ values.

[From Phillips and Tadayon, 2006]

\begin{tabular}{|c|c|c|}
\hline $\begin{array}{l}\text { Channel } \\
\text { conditions }\end{array}$ & $\begin{array}{c}\text { Manning's } n \\
\text { adjustment }\end{array}$ & Example \\
\hline \multicolumn{3}{|r|}{ Degree of irregularity } \\
\hline Smooth & 0.000 & Smoothest channel attainable in a given bed material \\
\hline Minor & $0.001-0.005$ & Channels with slightly scoured or eroded side slopes \\
\hline Moderate & $0.006-0.010$ & Channels with moderately sloughed or eroded side slopes \\
\hline Severe & $0.011-0.020$ & Channels with badly sloughed banks; unshaped, jagged, and irregular surfaces of channels in rock \\
\hline \multicolumn{3}{|r|}{ Variation in channel cross section } \\
\hline Gradual & 0.000 & Size and shape of channel cross sections change gradually \\
\hline $\begin{array}{l}\text { Alternating } \\
\text { occasionally }\end{array}$ & $0.001-0.005$ & $\begin{array}{l}\text { Large and small cross sections alternate occasionally, or the main flow occasionally shifts from side to side owing to } \\
\text { changes in cross section shape }\end{array}$ \\
\hline $\begin{array}{l}\text { Alternating } \\
\text { frequently }\end{array}$ & $0.010-0.015$ & $\begin{array}{l}\text { Large and small cross sections alternate frequently, or the main flow frequently shifts from side to side owing to } \\
\text { changes in cross section shape }\end{array}$ \\
\hline \multicolumn{3}{|r|}{ Effect of obstructions } \\
\hline Negligible & $0.000-0.004$ & $\begin{array}{l}\text { A few scattered obstructions, which include debris deposits, stumps, exposed roots, logs, piers, or isolated boulders, } \\
\text { which occupy less than } 5 \text { percent of the channel }\end{array}$ \\
\hline Minor & $0.005-0.015$ & $\begin{array}{l}\text { Obstructions occupy from } 5 \text { to } 15 \text { percent of the cross-sectional area and spacing between obstructions is such that } \\
\text { the sphere of influence around one obstruction does not extend to the sphere of influence around another obstruction. } \\
\text { Smaller adjustments are used for curved, smooth-surfaced objects than are used for sharp-edged, angular objects }\end{array}$ \\
\hline Appreciable & $0.020-0.030$ & $\begin{array}{l}\text { Obstructions occupy from } 15 \text { to } 50 \text { percent of the cross-sectional area, or the space between obstructions is small } \\
\text { enough to cause the effects of severe obstructions to be additive, thereby blocking an equivalent part of a cross section }\end{array}$ \\
\hline Severe & $0.040-0.060$ & $\begin{array}{l}\text { Obstructions occupy more than } 50 \text { percent of the cross-sectional area, or the space between obstructions is small } \\
\text { enough to cause turbulence across most of the cross section }\end{array}$ \\
\hline
\end{tabular}


Table 2. Adjustment factors or component ranges for various channel conditions used to determine Manning's $n$ values. - Continued

\begin{tabular}{|c|c|c|}
\hline $\begin{array}{l}\text { Channel } \\
\text { conditions }\end{array}$ & $\begin{array}{c}\text { Manning's } n \\
\text { adjustment }\end{array}$ & Example \\
\hline \multicolumn{3}{|r|}{ Amount of vegetation } \\
\hline Negligible & $0.000-0.002$ & Grass, shrubs, or weeds were permanently laid over during flow \\
\hline Small & $0.002-0.010$ & $\begin{array}{l}\text { Dense growths of flexible turf grass, such as Bermuda, or weeds growing where the average depth of flow is at least } \\
\text { two times the height of the vegetation where the vegetation is not laid over. Trees, such as willow, cottonwood, or } \\
\text { saltcedar, growing where the average depth of flow is at least three times the height of the vegetation. Flow depth is } \\
\text { about two times the tree height, and the trees are laid over }\end{array}$ \\
\hline Medium & $0.010-0.025$ & $\begin{array}{l}\text { Moderately dense grass, weeds, or tree seedlings growing where the average depth of flow is from two to three times } \\
\text { the height of vegetation; brushy, moderately dense vegetation, similar to } 1 \text { - to } 2 \text {-year-old willow trees growing along } \\
\text { the banks. A few } 8 \text { - to } 10 \text {-year old willow, cottonwood, mesquite, or palo verde, which block flow by approximately } \\
1 \text { to } 10 \text { percent, and spheres of influence or turbulence do not overlap }\end{array}$ \\
\hline Large & $0.025-0.050$ & $\begin{array}{l}\text { 8- to } 10 \text {-year-old willow, cottonwood, mesquite or palo verde trees (block flow by approximately } 10 \text { to } 30 \text { percent where } \\
\text { the spheres of influence overlap) intergrown with some weeds and brush where the hydraulic radius exceeds } 2 \text { feet. }\end{array}$ \\
\hline Very large & $0.050-0.100$ & $\begin{array}{l}\text { Bushy willow trees about } 1 \text { year old intergrown with weeds alongside slopes or dense cattails growing along the } \\
\text { channel bottom; trees intergrown with weeds and brush. Moderately dense } 8 \text { - to } 10 \text {-year old trees spaced randomly } \\
\text { throughout channel (blocks flow by approximately } 30 \text { to } 50 \text { percent and the spheres of influence overlap) where depth } \\
\text { of flow approximates height of vegetation }\end{array}$ \\
\hline $\begin{array}{l}\text { Extremely } \\
\text { large }\end{array}$ & $0.100-0.200$ & $\begin{array}{l}\text { Mature (greater than } 10 \text { years old) willow trees and tamarisk intergrown with brush and blocking flow by more than } \\
70 \text { percent of the flow area, causing turbulence across most of the section. Depth of flow is less than average height of } \\
\text { the vegetation. Dense stands of palo verde or mesquite that block flow by } 70 \text { percent or more and hydraulic radius is } \\
\text { about equal to or greater than average height of vegetation. }\end{array}$ \\
\hline \multicolumn{3}{|r|}{ Degree of meandering } \\
\hline Minor & 1.00 & Ratio of the channel length to valley length is 1.0 to 1.2 \\
\hline Appreciable & 1.15 & Ratio of the channel length to valley length is 1.2 to 1.5 \\
\hline Severe & 1.30 & Ratio of the channel length to valley length is greater than 1.5 \\
\hline
\end{tabular}

\section{Section V: Safety}


To prevent field hazards associated with stream gaging, the hydrographer needs to be aware of stream conditions at each site. Streams or washes should not be waded if the product of the depth of the stream (in feet) times the velocity (in feet per second) equals 10 or more. For example, if a stream is 4.5 feet deep and the velocity is 3.0 feet per second, then it would be considered unsafe as the product equals 13.5. Application of this rule varies among individuals, according to their weight and stature, and to the condition of the streambed. Personal floatation devices (PFDs) should be worn during stream conditions that may pose a drowning hazard.

During construction projects such as routine maintenance, installation of new gages, or installation of cableways, the hydrographer should wear appropriate protective clothing such as steel-toed boots and a hard hat. Long-sleeved shirts and pants will provide protection from sun exposure and help prevent skin contact with vegetation.

Preventative maintenance at streamflow gages will reduce field hazards. For example, cableways should be inspected on an annual basis by a qualified and trained hydrographer. The USGS can provide this service and appropriate training to the NDWR. Other preventative maintenance such as access trails or roads to the gage will reduce hazards associated with travel.

Unfortunately field hazards will occur at times so the hydrographer should carry an appropriate first-aid kit. Cuts, insect bites, and other potential injuries such as these will happen, and the hydrographer needs to be prepared to address them adequately when in the field. Some hazards that may seem to be minor can develop into a more serious situation and so seeking medical attention for certain injuries is a priority.

\section{Traffic Control}

Currently, the NDWR does not maintain any streamflow gages near roadsides where traffic control is needed. However, if such sites are added to the gaging network, a traffic and bridge safety plan should be developed. The USGS and the Arizona Department of Transportation can provide assistance with developing this plan. 
Table 3. Example of a primary job hazard analysis checklist associated with servicing field sites.

[PFD, personal flotation device]

\begin{tabular}{|c|c|c|}
\hline Sequence of basic job steps & $\begin{array}{l}\text { Potential accidents/ } \\
\text { hazards }\end{array}$ & Recommended safe job procedures \\
\hline Loading equipment & $\begin{array}{l}\text { Pinching fingers, } \\
\text { mashing toes, back } \\
\text { strain }\end{array}$ & $\begin{array}{l}\text { Use caution, be aware of hand placement, use proper lifting techniques (for } \\
\text { example, lift with legs not back, get assistance as necessary). Wear gloves, steel- } \\
\text { toed shoes, and back support. }\end{array}$ \\
\hline Driving to the job site & Traffic accident & $\begin{array}{l}\text { Stay alert to driving conditions and obey all traffic laws. Reduce speed for } \\
\text { hazardous conditions. }\end{array}$ \\
\hline Parking the vehicle & Vehicle safety & Park as far from roadway as possible. Use hazard warning lights and light bar. \\
\hline Determining type of task to be done & Traffic \& personal safety & Stay alert to traffic and surroundings. Wear reflective vest or PFD as necessary. \\
\hline Setting up traffic control equipment & Traffic \& personal safety & Be alert to traffic conditions. \\
\hline Removing traffic control equipment & Traffic \& personal safety & Be alert to traffic conditions. \\
\hline Driving to the office & Traffic accident & $\begin{array}{l}\text { Stay alert to driving conditions and obey all traffic laws. Reduce speed for } \\
\text { hazardous conditions. }\end{array}$ \\
\hline Unloading equipment & $\begin{array}{l}\text { Pinching fingers, } \\
\text { mashing toes, back } \\
\text { strain }\end{array}$ & $\begin{array}{l}\text { Use caution, be aware of hand placement, use proper lifting techniques (for } \\
\text { example, lift with legs not back, get assistance as necessary). Wear gloves, steel- } \\
\text { toed shoes, and back support. }\end{array}$ \\
\hline \multicolumn{3}{|c|}{ Recommended protective clothing and equipment } \\
\hline loginmont & hard hat cafetv & ses, gloves, steel-toed shoes, and back support \\
\hline
\end{tabular}


Table 4. Example of a primary job hazard analysis checklist associated with environmental hazards.

[PFD, personal flotation device]

\begin{tabular}{|c|c|c|}
\hline $\begin{array}{l}\text { Sequence of } \\
\text { basic job steps }\end{array}$ & Potential accidents/hazards & Recommended safe job procedures \\
\hline \multirow{11}{*}{$\begin{array}{l}\text { Walking to, } \\
\text { from, and } \\
\text { around field } \\
\text { site }\end{array}$} & Trips and falls & $\begin{array}{l}\text { Ensure path is clear and free of obstructions. Ensure that footing at the field site work area is } \\
\text { sound. }\end{array}$ \\
\hline & Lightning strikes & Do not work around or during thunder storms. \\
\hline & $\begin{array}{l}\text { Dehydration, heat exhaustion, } \\
\text { or sun stroke }\end{array}$ & In warm or hot weather, rest often and drink plenty of water or electrolyte drink. \\
\hline & Hypothermia or frostbite & Wear foul-weather gear during winter months. \\
\hline & Sunburn & Protect yourself from sun. Use sunblock, wear light-protective clothing, sunglasses, and hat. \\
\hline & Bruise, sprain, sting & Use caution and walk appropriately for the circumstances. \\
\hline & Slippery conditions & Use appropriate foot wear when mud, snow, or ice conditions exists. \\
\hline & Snake bites & $\begin{array}{l}\text { Wear appropriate foot and leg protection. If you are bitten seek medical help immediately. DO } \\
\text { NOT "cut and suck." This may make the bite worse. }\end{array}$ \\
\hline & Attack by wild animals & Be familiar with animal behavior. \\
\hline & Insect bites or stings & $\begin{array}{l}\text { Wear appropriate insect repellant. At the end of work day check your body carefully for ticks. } \\
\text { Avoid wasps or hornets nests. }\end{array}$ \\
\hline & Poisonous plants & Wear appropriate clothing. Wash all exposed areas of skin with cold water only. \\
\hline
\end{tabular}


Table 4. Example of a primary job hazard analysis checklist associated with environmental hazards.-Continued

\begin{tabular}{|c|c|c|}
\hline $\begin{array}{l}\text { Sequence of } \\
\text { basic job steps }\end{array}$ & Potential accidents/hazards & Recommended safe job procedures \\
\hline \multirow{3}{*}{$\begin{array}{l}\text { Opening gage } \\
\text { house or other } \\
\text { type shelter }\end{array}$} & Insect bites or stings & Check carefully around shelter for wasps or spiders. Use sprays (wasp stopper) to kill insects. \\
\hline & Snake bites & Check carefully around and inside shelter for snakes. \\
\hline & Infectious diseases & $\begin{array}{l}\text { Watch for bats, rodent nests, or droppings. If a nest or droppings are present, special } \\
\text { precautions must be taken to prevent illness or death. See cleaning protocol. }\end{array}$ \\
\hline \multirow{4}{*}{$\begin{array}{l}\text { Working in or } \\
\text { around surface } \\
\text { waters }\end{array}$} & Infectious water-borne diseases & Wear appropriate gloves. Prevent water from contacting your skin. \\
\hline & Contaminated water source & $\begin{array}{l}\text { Wear appropriate gloves. Prevent water from contacting your skin. Work in well-ventilated } \\
\text { area. }\end{array}$ \\
\hline & Snake bites & $\begin{array}{l}\text { Wear appropriate foot and leg protection. If you are bitten, seek medical help immediately. } \\
\text { DO NOT "cut and suck." This may make the bite worse. }\end{array}$ \\
\hline & Drowning / rapidly rising stage & $\begin{array}{l}\text { Wear PFD. Be familiar with weather conditions occurring upstream. Be prepared to move to } \\
\text { higher ground. }\end{array}$ \\
\hline \multicolumn{3}{|r|}{ Recommended protective clothing and equipment } \\
\hline
\end{tabular}

Safety glasses, gloves, footwear, PFD, electrolyte drink, sunblock, sunglasses, protective clothing, foul-weather gear, insect repellent, rope, and shovel 
Table 5. Example of a primary job hazard analysis checklist associated with cableway measurement.

[PFD, personal flotation device]

\begin{tabular}{lll}
\multicolumn{1}{c|}{ Sequence of basic job steps } & \multicolumn{1}{c}{ Potential accidents/hazards } & \multicolumn{1}{c}{ Recommended safe job procedures } \\
\hline $\begin{array}{l}\text { Unloading equipment from vehicle } \\
\text { and moving equipment to cablecar }\end{array}$ & $\begin{array}{l}\text { Pinching fingers, mashing toes, } \\
\text { back strain }\end{array}$ & $\begin{array}{l}\text { Use caution, be aware of hand placement, use proper lifting techniques } \\
\text { (lift with legs not back, get assistance as necessary). Wear gloves, } \\
\text { steel-toed shoes, and back support. }\end{array}$ \\
\hline Making measurement & $\begin{array}{l}\text { Structure failure, fall from tower } \\
\text { or cable car, floating or submerged } \\
\text { debris }\end{array}$ & $\begin{array}{l}\text { Wear PFD. Do not climb ladders while carrying other equipment. Be } \\
\text { alert to debris, have cutters ready if sounding cable needs to be cut. }\end{array}$ \\
\hline $\begin{array}{l}\text { Moving equipment from cablecar } \\
\text { to vehicle and reloading equipment }\end{array}$ & $\begin{array}{l}\text { Pinching fingers, mashing toes, } \\
\text { back strain }\end{array}$ & $\begin{array}{l}\text { Use caution, be aware of hand placement, use proper lifting techniques } \\
\text { (lift with legs not back, get assistance as necessary). Wear gloves, } \\
\text { steel-toed shoes, and back support. }\end{array}$ \\
\hline Gloves, steel-toed shoes, back support, PFD, cable cutters & \multicolumn{1}{c}{ Recommended protective clothing and equipment: } \\
\hline
\end{tabular}


Table 6. Example of a primary job hazard analysis checklist associated with wading measurements.

\begin{tabular}{|c|c|c|}
\hline $\begin{array}{l}\text { Sequence of } \\
\text { basic job steps }\end{array}$ & $\begin{array}{l}\text { Potential accidents/ } \\
\text { hazards }\end{array}$ & Recommended safe job procedures \\
\hline \multirow[t]{3}{*}{$\begin{array}{l}\text { Entering } \\
\text { stream }\end{array}$} & Submerged debris & $\begin{array}{l}\text { Proceed slowly, testing the bottom with your wading rod. Urban streams near bridges could have a wide } \\
\text { variety of junk discarded over the bridge. }\end{array}$ \\
\hline & Floating debris & Be aware of surroundings; watch upstream for drift. \\
\hline & Soft stream bottom & Use the wading rod to test bottom before stepping. \\
\hline \multirow[t]{3}{*}{$\begin{array}{l}\text { Stringing } \\
\text { tagline }\end{array}$} & $\begin{array}{l}\text { Slippery concrete or rock } \\
\text { bottom due to algae }\end{array}$ & $\begin{array}{l}\text { Wear steel "creepers" on boots or waders for traction. Wear waders with nonslip soles. Do not enter } \\
\text { concrete flood channels except during low flow and fair weather. }\end{array}$ \\
\hline & High velocity or depth & $\begin{array}{l}\text { Check field folder for safe limits. Know your own limits. If velocities become too high, do not try to } \\
\text { turn around midstream, back out. }\end{array}$ \\
\hline & Boat traffic & $\begin{array}{l}\text { Use flags on tagline. Have cutters ready. Have a second person on shore to warn boating traffic. Use } \\
\text { alternate ways to measure distance such as a handheld laser range finder. Wear highly visible clothing. }\end{array}$ \\
\hline \multirow[t]{4}{*}{$\begin{array}{l}\text { Making } \\
\text { measurement }\end{array}$} & Hypothermia & $\begin{array}{l}\text { Wear flotation gear that also helps keep you warm such as a float coat. Wear foul weather gear. Keep } \\
\text { waders and hip boots in good condition. Have extra set of clothes. }\end{array}$ \\
\hline & Sun and heat exposure & Use sunscreen, wear hat, drink liquids. Learn to recognize heat exhaustion, heat stroke, and dehydration. \\
\hline & Lightning & Do not enter stream if there is lightning is in the area. \\
\hline & Rapidly rising stage & $\begin{array}{l}\text { Check weather forecast. Know how your site responds to local rain storms or how it responds to rain } \\
\text { upstream in the drainage. Do not enter water during significant rainfall. Exit stream before conditions } \\
\text { become unsafe. If necessary, throw tagline in stream and retrieve at lower stage. }\end{array}$ \\
\hline $\begin{array}{l}\text { Removing } \\
\text { tagline }\end{array}$ & Tagline getting snagged & $\begin{array}{l}\text { Carefully wade out to snag and free or cut tagline. If stage or velocity increase dangerously, abandon tag } \\
\text { line and recover it at a lower stage. }\end{array}$ \\
\hline Exiting stream & $\begin{array}{l}\text { Slippery surfaces, steep } \\
\text { banks, undercut banks, } \\
\text { debris piles }\end{array}$ & $\begin{array}{l}\text { Wear PFD and felt or other nonslip soles. Use wading rod for support. Cut temporary steps into bank. } \\
\text { Use rope tied to tree or other support for help. Grab tree limbs or branches cautiously, they may have } \\
\text { thorns or be poison oak, for example. }\end{array}$ \\
\hline
\end{tabular}

\section{Section V: Safety}




\section{Section VI: Selected Streamflow-Gaging Terms}

This section provides an explanation of some of the more common hydrologic terms. The USGS maintains various online water resource glossaries (http://water.usgs.gov/glossaries. html) that provide detailed explanations of an extensive range of hydrologic terms.

Base flow is the flow of a stream that does not reflect direct surface-water runoff. Base flow is usually groundwater discharge from the local aquifer, but it can also be artificially induced by effluent discharge (return flows) from water-treatment facilities.

Channel roughness is a measure of the resistance to flow created by the channel material. The roughness of a channel is typically represented by a roughness parameter, such as Manning's $n$ (see Phillips and Tadayon, 2006; and Aldridge and Garrett, 1973).

Continuous slope-area (CSA) method, which expands on the slope-area method of computing high flow, was developed by the USGS to estimate a complete flow-event hydrograph. Both methods allow the hydrographer to produce more complete discharge records than would otherwise be possible because of resource limitations or logistical obstacles. Continuously recording pressure transducers are installed and their measurements of water-surface slopes and stages are used to generate continuous hydrographs and rating curves (Smith and others, 2010).

Crest-stage gage (CSG) is a device for obtaining the highest stage (peak stage) that occurs during a flow event. It is a simple measuring device that consists of a steel pipe (of varying lengths), a wooden ruler that fits inside the pipe, a slotted end cap that allows water to enter the pipe, and a fine-grained cork, which floats and adheres to the wooden ruler at the level of the highest stage. CSGs also can be instrumented with a pressure transducer as a means for recording the entire flow event in conjunction with the ruler and cork method. A series of CSGs can also be installed and instrumented with a continuous recording pressure transducer (see CSA, above) in a reach upstream or downstream of the gage for use in indirect measurements. CSGs are useful for documenting the peak stage for comparison with the primary gage record.

Discharge, or flow, is the amount of water that passes by the gaging station per unit of time, which is typically expressed in cubic feet per second ( $\mathrm{ft}^{3} / \mathrm{s}$ or $\mathrm{cfs}$ ) or gallons per minute (gal/ min or gpm). Discharge is computed, not measured. Using the 
velocity and the area (depth multiplied by width) measured at about 25 locations along the measuring section, the hydrographer computes the total discharge for the stream at the time of the measurement. The total discharge is referred to as streamflow.

Flow meters are instruments used to measure the speed of the water, or velocity, expressed in feet per second. Flow meters are either mechanical or acoustic. Mechanical meters include several types, but the most common are the Price AA current meter and the Price Pygmy current meter. A mechanical meter has a wheel of six metal cups that revolve around a vertical axis, much like a windmill. The revolutions are counted and timed by the hydrographer using a headset and stopwatch to determine the speed of the water. Acoustic flow meters (such as the FlowTracker Handheld-AVD ${ }^{\circledR}$ (acoustic Doppler velocimeter) made by SonTek) sense the speed of the stream from the acoustic Doppler effect of suspended particles moving in the stream. The transmitter of the flow meter sends multiple sound signals through the water that bounce off suspended particles in the water. The reflected sound signals that return to the receiver of the flow meter have a modified frequency that is related to the velocity of the suspended particles.

Flumes are artificial channels used to make discharge measurements; they consist of a converging section, a throat section, and a diverging section. The constricted throat produces a head that is related to the discharge. The flow rate through the flume is a function of the liquid level at head of the flume. A Parshall flume is one of the most commonly used flumes (Rantz and others, 1982, v. 2).

Gage datum "is a horizontal surface used as a zero point for measurement of stage or gage height. This surface usually is located slightly below the lowest point of the stream bottom such that the gage height is usually slightly greater than the maximum depth of water. Because the gage datum is not an actual physical object, the datum is usually defined by specifying the elevations of permanent reference marks such as bridge abutments and survey monuments (brass tablets), and the gage is set to agree with the reference marks. Gage datum is a local datum that is maintained independently of any national geodetic datum. However, if the elevation of the gage datum relative to the national datum (National Geodetic Vertical Datum of 1929 or North American Vertical Datum of 1988) has been determined, then the gage readings can be converted to elevations above the national datum by adding the elevation of the gage datum to the gage reading (Kenney, 2010)."

Gage pool, or reach, is the part of the stream channel that is created by the stage control and represents the conditions of the stream for physical, chemical, and biological characteristics. It is

\section{Section VI: Selected Streamflow-Gaging Terms}


the gage pool that is being monitored for changes by gage sensors such as a stilling-well float.

High-water marks (HWMs) are natural indicators of the highest level reached by a body of water. A debris line, seed line, or wash line forms along the banks of the stream resulting from high water. HWMs are usually visible along streambanks, trunks of large trees, and boulders, as well as inside stilling wells. The crest-stage gage is used to document HWMs. The HWM is the highest level or stage of the flow event and can be used to verify the gage record or used in determining discharge using indirect methods.

Orifice line is part of a gas-purge system that transmits the pressure head of water in the stream to the pressure transducer location. The pressure in the gas line of the gas-purge system is equal to the pressure head of the stream. When the stream stage changes (increasing or decreasing head pressure), the gas-purge system responds accordingly.

Peak-stage indicator (PSI) is a clip that attaches to the steel tape of a float-driven encoder and moves along the tape as the stage rises. The PSI is set under the shelf where the steel tape passes through from the float to the encoder. The PSI will mark the highest peak stage that occurred between site visits.

Reference gage, staff plate, or staff gage is a graduated ruler used to reference to the primary gage. It is read during each rou- tine field trip to the gage to verify that the recording gage (the primary gage record) is sensing or measuring the stage (gage height) correctly by observing the water level on the staff plate. Staff plates should be mounted vertically on the inside (if using a stilling well) and outside of the gage structure or near the gaging station.

Reference point (RP) is a permanent marker such as a lag bolt inserted into a rock or some other solid feature. The RP is located near the gaging station where the hydrographer can tape down from it to the water surface to measure the stage of the stream gage pool with a graduated measuring tape or ruler. Like the reference gage, the RP is another way to verify that the recording gage is reading and recording accurately. The RP is also used to maintain datum integrity for the gage.

Strip chart recorders predate electronic data loggers and use a roll or strip of paper that is passed beneath one or more ink pens to record data. The strip chart recorder does not sense the stage but records the response of the stage from a float-driven stage sensor. Strip chart recorders, including the Stevens A-71, are used at some Navajo Nation gaging stations.

Stage, or gage height, is simply the water-surface elevation above or below a vertical reference point, which is often close to the streambed, used as a zero point for measurements. Stage is typically measured in feet and to the nearest $0.01 \mathrm{ft}$. An experienced hydrog- 
rapher can use stage to determine low-, medium-, or high-water conditions. After a stage-discharge rating curve (see definition in this section of the report) is developed for a site, the hydrographer can use the stage to determine the discharge before going in the field. See figure 4 for examples of instruments used to measure stage.

Stage controls are physical features in the stream channel that affect or control the stage. The stage control determines the stage-discharge relation at the gage. There are various types of stage controls, including (1) a constriction of the channel, (2) a bedrock outcrop, (3) a gravel bar, and (4) an artificial structure (such as a V-notch weir or low-water road crossing), which is usually effective for low stages. A uniform cross-section control over a long reach of the channel is effective for medium to high stages. The control is sensitive to changes that may occur in the gaged reach. These changes can be caused by aquatic growth, accumulation of debris or sediment, and scour of vegetation, sediment, or bed material. The following are typical controls for low stages that exist at Navajo streamflow gages (fig. 3):

1. Constriction control is caused by the narrowing of the channel that controls the stage of the gage pool. This type of control is effective for medium and high stages, but also low stage depending on the site. An example of this exists at Black Creek, Navajo Nation.

\section{Section VI: Selected Streamflow-Gaging Terms}

2. Bedrock control is an outcrop of rock that is exposed in the stream channel and is effective for low stage in the gage pool. An example of this stage control exists at the Wheatfields Creek, Navajo Nation.

3. Gravel bar control, or cobble control, is a feature of the channel where coarse bed material (such as gravel) exists, which is effective during low stage of the gage pool. An example of this stage control exists at the Asaayi Creek, Navajo Nation.

4. Artificial control is a manmade feature and can include a Vnotch weir (typically constructed of steel) or a low-water road crossing (constructed of concrete). These features are excellent stage controls, particularly at low stages, but a low-water crossing may also be effective for medium to higher stages. An example of this stage control exists at Whiskey Creek, Navajo Nation.

These low-stage controls are normally submerged at medium to higher stages when the channel's roughness and geometry below the gage pool becomes the control and is referred to as a channel control. Compound controls exist at most Navajo streamflow-gaging sites because of the channel characteristics. Compound controls consist of the types of low-stage controls described above and the channel control for medium to high stages. 
Stage-discharge relation, or rating curve, is the relation between the gage height, usually plotted as ordinate, and the amount of water flowing in a channel, expressed as volume per unit of time, plotted as abscissa (http://water.usgs.gov/wsc/glossary. html\#Stagedischargecurve). The stage-discharge relation is developed by making numerous measurements of discharge at different stages. The discharge is referenced to the stage at the time the discharge measurement was made. A rating curve is then developed from this relationship that covers the range in stage for the gage site. The stage-discharge relation at a gage is unique to each gage site.

Stage sensors are instruments that measure the level of the stream on a continuous basis and are referred to as the primary gage. There are many types of stage sensors including (1) floatdrive encoders, (2) gas-purge systems, (3) pressure transducers, and (4) noncontact sensors such as radar systems. These instruments respond to the changing stage at the gage. On the Navajo Nation, the typical sensors used are the stilling-well floats or pressure transducers (see fig. 4).

Volumetric method is a method of discharge measurement that is only applicable to small discharges, but it is the most accurate method of measuring such flows. The method requires measuring the time required to fill a container of a known capacity, or the time required to partly fill a calibrated container to a known volume. The only equipment required is a stopwatch and container.

\section{Section VII: Additional Resources by Category}

\section{Instrumentation Resources}

U.S. Geological Survey Hydrologic Instrumentation Facility, http://water.usgs.gov/hif

\section{Streamflow Gage Operation}

Olsen, S.A., and Norris, J.M., 2007, U.S. Geological Survey streamgaging...from the National Streamflow Information Program: U.S. Geological Survey Fact Sheet 2005-3131, 4 p., http://pubs.usgs.gov/fs/2005/3131/FS2005-3131.pdf.

Sauer, V.B., and Turnipseed, D.P., 2010, Stage measurement at gaging stations: U.S. Geological Survey Techniques and Methods, book 3, chap. A7, 45 p., http://pubs.usgs.gov/tm/tm3-a7/.

Kenney, T.A., 2010, Levels at gaging stations: U.S. Geological Survey Techniques and Methods, book 3, chap. A19, 60 p., http://pubs.usgs.gov/tm/tm3A19/. 


\section{Measurements of Streamflow}

Nolan, K.M., Frey, C., and Jacobson, J., 1998, Surface-water field techniques training class (online training class, last updated May 2, 2008): U.S. Geological Survey Water-Resources Investigations Report 98-4252, available at http://wwwrcamnl. wr.usgs.gov/sws/SWTraining/FlashFandR/Index.html.

Nolan, K.M., and Shields, R.R., Measurement of stream discharge by wading (online training class, last updated Dec. 16, 2010): U.S. Geological Survey Water-Resources Investigations Report 00-4036, version 1.1, available at http://training.usgs. gov/ntc/courses/cbt-cdrom/wrir00-4036.html.

Rantz, S.E., and others, 1982, Measurement of stage and discharge, vol. 1 in Rantz, S.E., and others, Measurement and computation of streamflow: U.S. Geological Survey Water Supply Paper 2175, 284 p.

Rantz, S.E., and others, 1982, Computation of discharge, vol. 2 in Rantz, S.E., and others, Measurement and computation of streamflow: U.S. Geological Survey Water Supply Paper 2175, 346 p.

Turnipseed, D.P., and Sauer, V.B., 2010, Discharge measurements at gaging stations: U.S. Geological Survey Techniques and Methods, book 3, chap. A8, 87 p., http://pubs.usgs.gov/tm/ tm3-a8/.

\section{Section VII: Additional Resources by Category}

\section{Measurement of Peak Flow Discharge Using Surveying Methods}

Aldridge, B.N., and Garrett, J.M., 1973, Roughness coefficients for stream channels in Arizona: U.S. Geological Survey OpenFile Report 73-3, 87 p., http://pubs.er.usgs.gov/publication/ ofr733.

Arcement, G.J., Jr., and Schneider, V.R., 1989, Guide for selecting Manning's roughness coefficients for natural channels and flood plains: U.S. Geological Survey Water-Supply Paper 2339, 44 p.

Dalrmyple, T., and Benson, M.A., 1984, Measurement of peak discharge by the slope-area method: U.S. Geological Survey Techniques of Water-Resources Investigations, chap. A2, book 3, $12 \mathrm{p}$.

Fulford, J.M., 1994, User's guide to SAC, a computer program for computing discharge by the slope-area method: U.S. Geological Survey Open-File Report 94-360, 31 p.

Hortness, J.E., 2004, SAM 2.1-A computer program for plotting and formatting surveying data for estimating peak discharges by the slope-area method: U.S. Geological Survey Fact Sheet 2004-3028, 4 p., http://pubs.usgs.gov/fs/2004/3028/. 


\section{Acknowledgments}

The Navajo Field Manual was prepared, reviewed, and field tested by professional hydrographers at the Navajo Department of Water Resources (NDWR) and the U.S. Geological Survey (USGS). The authors would like to give special thanks to NDWR Hydrologist Bel B. Pachhai and NDWR hydrologic technicians Irving Brady and Jerome Bekis for their support and assistance in preparing this field manual. The authors also wish to recognize the many USGS Arizona Water Science Center hydrologists and hydrologic technicians who provided field training and conducted surface-water record computations for the NDWR. Also, thanks to Jon Mason, USGS, for many photos used in this guide.

\section{References}

Aldridge, B.N., and Garrett, J.M., 1973, Roughness coefficients for stream channels in Arizona: U.S. Geological Survey OpenFile Report 73-3, 87 p., http://pubs.er.usgs.gov/publication/ ofr733.

Arcement, G.J., Jr. and Schneider, V.R., 1989, Guide for selecting Manning's roughness coefficients for natural channels and flood plains: U.S. Geological Survey Water-Supply Paper 2339, 44 p.
Benson, M.A., and Dalrymple, T., 1967, General field and office procedures for indirect discharge measurements: U.S. Geological Survey Techniques of Water-Resources Investigations, book 3, chap. A1, 35 p.

Dalrymple, T., and Benson, M.A., 1984, Measurement of peak discharge by the slope-area method: U.S. Geological Survey Techniques of Water-Resources Investigations, book 3, chap. A2, $12 \mathrm{p}$.

Fulford, J.M., 1994, User's guide to SAC, a computer program for computing discharge by the slope-area method: U.S. Geological Survey Open-File Report 94-360, 31 p.

Hortness, J.E., 2004, SAM 2.1-A computer program for plotting and formatting surveying data for estimating peak discharges by the slope-area method: U.S. Geological Survey Fact Sheet 2004-3028, 4 p., http://pubs.usgs.gov/fs/2004/3028/.

Kenney, T.A., 2010, Levels at gaging stations: U.S. Geological Survey Techniques and Methods, book 3, chap. A19, 60 p.

Nolan, K.M., Frey, C., and Jacobson, J., 1998, Surface-water field techniques training class (online training class, last updated May 2, 2008): U.S. Geological Survey Water-Resources Investigations Report 98-4252, at http://wwwrcamnl.wr.usgs.gov/ sws/SWTraining/FlashFandR/Index.html. 
Nolan, K.M., and Shields, R.R., Measurement of stream discharge by wading (online training class, last updated Dec. 16, 2010): U.S. Geological Survey Water-Resources Investigations Report 00-4036, version 1.1, http://training.usgs.gov/ ntc/courses/cbt-cdrom/wrir00-4036.html.

Olsen, S.A., and Norris, J.M., 2007, U.S. Geological Survey streamgaging... from the National Streamflow Information Program: U.S. Geological Survey Fact Sheet 2005-3131, 4 p., http://pubs.usgs.gov/fs/2005/3131/FS2005-3131.pdf.

Phillips, J.V., and Tadayon, S., 2006, Selection of Manning's roughness coefficient for natural and constructed vegetated and nonvegetated channels, and vegetation maintenance plan guidelines for vegetated channels in central Arizona: U.S. Geological Survey Scientific Investigations Report 20065108, 41 p., http://pubs.usgs.gov/sir/2006/5108/.

Rantz, S.E., and others, 1982, Measurement of stage and discharge, vol. 1 in Rantz, S.E., and others, Measurement and computation of streamflow: U.S. Geological Survey Water Supply Paper 2175, 284 p.
Rantz, S.E., and others, 1982, Computation of discharge, vol. 2 in Rantz, S.E., and others, Measurement and computation of streamflow: U.S. Geological Survey Water Supply Paper 2175, $346 \mathrm{p}$.

Sauer, V.B., and Turnipseed, D.P., 2010, Stage measurement at gaging stations: U.S. Geological Survey Techniques and Methods, book 3, chap. A7, 45 p., http://pubs.usgs.gov/tm/tm3-a7/.

Smith, C.F., Cordova, J.T., and Wiele, S.M., 2010, The continuous slope-area method for computing event hydrographs: U.S. Geological Survey Scientific Investigations Report 2010-5241, $37 \mathrm{p}$.

Turnipseed, D.P., and Sauer, V.B., 2010, Discharge measurements at gaging stations: U.S. Geological Survey Techniques and Methods, book 3, chap. A8, 87 p., http://pubs.usgs.gov/tm/tm3-a8/.

Wilde, F.D., Radke, D.B., Gibs, J., and Iwatsubo, R.T., 1998, National field manual for the collection of water-quality data: U.S. Geological Survey Techniques of Water-Resources Investigations, book 9, chap. A1-A9. 
This page left intentionally blank. 
Menlo Park Publishing Service Center, California

Manuscript approved for publication February 20, 2013

Edited by Larry B. Slack and Claire M. Landowski

Design and layout by Jeanne S. DiLeo 


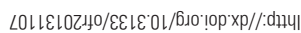

(әи!|น0) 89Zl-เEZZ NSS|

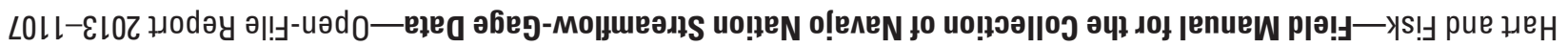

